\title{
DETECÇÃO DO DNA DO POLIOMAVÍRUS HUMANO JC EM AMOSTRAS DE LÍQUIDO CEFALORRAQUIDIANO DE PACIENTES COM AIDS E LESÕES NÃO EXPANSIVAS DE SUBSTÂNCIA BRANCA DO SISTEMA NERVOSO CENTRAL
}

Dissertação apresentada a Facudade de Medicina da Universidade de São Paulo para obtenção do título de Mestre em Ciências.

Área de concentração:

Doenças Infecciosas e Parasitárias

Orientador: Prof. Dr. Cláudio Sérgio Pannuti

SÃO PAULO 


\section{FICHA CATALOGRÁFICA}

\section{Preparada pela Biblioteca da \\ Faculdade de Medicina da Universidade de Săo Paulo}

Creprodução autorizada pelo autor

Fink, Maria Cristina Domingues da Silva

Deteçăo do DNA do Poliomavirus humano JC em amostras de líquido cefalorraquidiano de pacientes com aids e lesర̄es não expansivas de substância branea do sistema nervoso central / Maria Cristina Domingues da Silva Fink. -São Paulo, 2004.

Dissertação(mestrado)--Faculdade de Medicina da Universidade de São Paulo. Departamento de Moléstias Infecciosas e Parasitárias.

Área de concentração: Doenças Infecciosas e Parasitárias.

Orientador: Cláudio Sergio Pannuti.

Descritores: I.LEUCOENCEFALOPATIA MULTIFOCAL PROGRESSIVA diagnóstico 2.LEUCOENCEFALOPATIA MULTIFOCAL PROGRESSIVA líquido céfalo-raquidiano 3.SÍNDROME DA IMUNODEFICIÊNCIA ADQUIRIDA/complicaçōes 4.POLYOMAVIRUS HOMINIS 2 5.ESTUDOS TRANSVERSAIS 


\section{DEDICATÓRIA}

Ao meu pai, exemplo de dignidade, amor e trabalho.

A minha mãe, tão querida, que, onde estiver, participa comigo deste momento.

Ao Paulo, por todos estes anos de convívio, por seu estímulo e apoio irrestritos, por acreditar em mim e neste trabalho.

Às grandes bênçãos de minha vida: Rafa, Bia, Marinho, Dudu.

Às mais que amigas, verdadeiramente, minhas irmãs, Laura, Cynthia e Jussara.

A Sra Ercília Pinheiro, por me ensinar, com sua força e sabedoria, a superar todos os percalços da vida.

A Deus, acima de tudo. 
A Elisabete da Conceição Ferreira, saudades... 


\section{AGRADECIMENTOS}

Ao Dr. Cláudio Sérgio Pannuti, por assumir a orientação deste trabalho, aumentando em mim a admiração e o respeito pelo ser humano e o grande pesquisador que é.

Ao Dr. Augusto César Penalva De Oliveira, que acreditou neste projeto e ajudou-me a torná-lo viável, com seu apoio irrestrito e sugestões precisas em todas as suas etapas.

A Dra. Vanda Akico Ueda Fick De Souza, minha eterna professora, por seu estímulo, auxílio e valiosas contribuições, não apenas neste trabalho, mas em toda a minha vida.

A Lucy Santos Vilas Bôas, por sua competência e profissionalismo, que muito tem contribuído para meu crescimento pessoal e profissional.

A Dra. Clarisse Martins Machado, por suas valiosas sugestões e correções neste trabalho.

A equipe do setor de biologia molecular, do laboratório de Sorologia do IMT, em especial a Sueli Fátima de Bastos e Adriano Cappelazzo Coelho, que tão gentilmente me acolheram em seu laboratório e que, com muita competência 
e interesse, possibilitaram a clonagem do vírus, etapa indispensável no desenvolvimento deste trabalho.

Ao Dr. José Eduardo Levi, por sua disponibilidade e competência, esclarecendo minhas dúvidas, contribuindo de forma decisiva para a conclusão deste trabalho.

A Nadily e Silva Carretiero, por sua colaboração, dedicada e competente, na execução das reações.

A todos os médicos e chefes de clínicas do Instituto de Infectologia Emílio Ribas e Hospital das Clínicas da Faculdade de Medicina da USP, por sua inestimável contribuição na seleção e avaliação dos pacientes, meus sinceros agradecimentos.

Ao Dr. José Marcos Pereira Costa, diretor do laboratório clínico do IIER e, a Dra. Patrícia Novoa, chefe do setor de líqüor e todos os seus funcionários, pelo fornecimento das amostras utilizadas na padronização da PCR.

Ao Dr. Heitor Franco de Andrade Junior que, com sua boa vontade característica e enorme competência, muito contribuiu para a realização deste trabalho. 
Ao Dr. Aluisio Augusto Cotrim Segurado que, com sua competência e brilhantismo muito contribuiu na qualificação deste trabalho, tornando-o mais claro e preciso.

Aos funcionários da biblioteca do Instituto de Medicina Tropical de São Paulo, em especial a Sonia Pedroso, sempre prestativos e eficientes.

A todos os funcionários do Instituto de Medicina Tropical de São Paulo, por sua contribuição no desenvolvimento e conclusão deste trabalho.

A Rosimeire Aparecida Morais Ribeiro e Roseli Antonia Santo, secretárias da Pós-graduação do Departamento de Doenças Infecciosas e Parasitárias da FMUSP, pelas constantes demonstrações de amizade e carinho, além da competência e responsabilidade com que orientam nossos passos dentro do programa de pós-graduação. 
Agradeço, especialmente, a todos os queridos amigos do Laboratório de Virologia do IMT, pela agradável convivência, por compartilharem comigo este momento tão especial de minha vida. 


\section{SUMÁRIO}

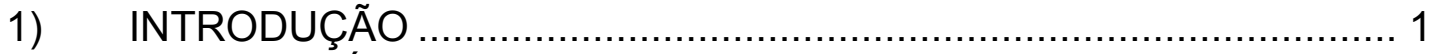

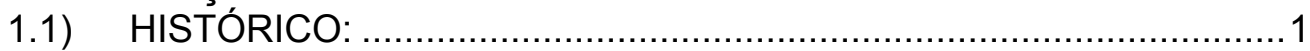

1.2) CLASSIFICAÇÃO................................................................ 1.2.1) OUTROS POLIOMAVIRUS RELEVANTES EM DOENÇAS HUMANAS

1.3) ESTRUTURA GENÔMICA ......................................................

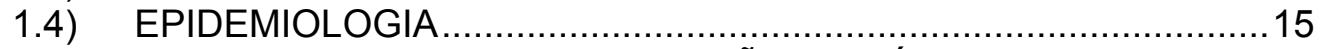

1.4.1) FORMAS DE TRANSMISSÃO DO VÍRUS ………............15

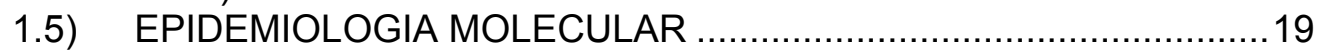

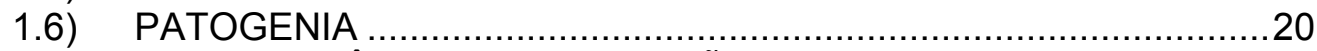

1.6.1) LATÊNCIA E REATIVAÇÃO ……....................................20

1.7) PATOGÊNESE DA LEUCOENCEFALOPATIA MULTIFOCAL

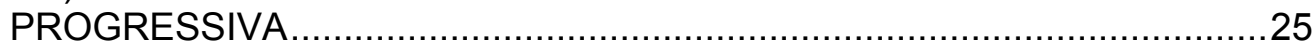

1.8) MANIFESTAÇÕES CLÍNICAS ……………….........................29

1.8.1) MÉTODOS DIAGNÓSTICOS DE NEUROIMAGEM …..........30

1.9) DIAGNÓSTICO LABORATORIAL E TRATAMENTO ……................32

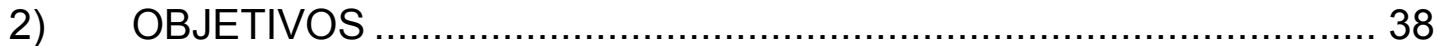

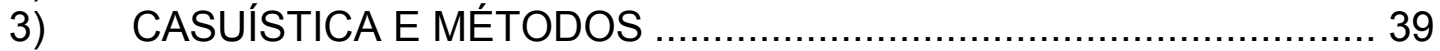

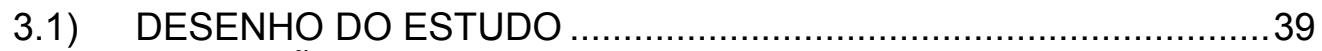

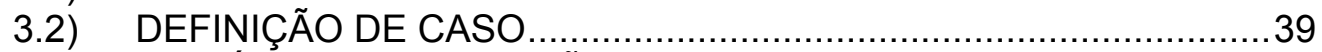

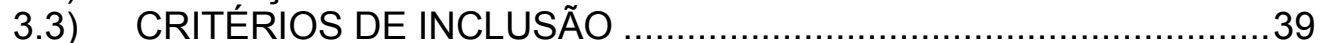

3.4) CRITÉRIOS DE EXCLUSÃO ……………………........................

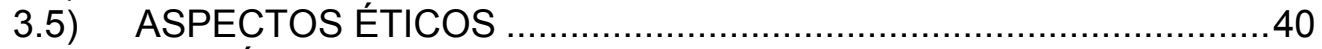

3.6) CASUÍSTICA ....................................................................... 40

3.7) MÉTODOS LABORATORIAIS ……………….................................

3.7.1) COLETA DE LÍQÜOR ……………………………....... 40

3.7.2) PROCESSAMENTO DAS AMOSTRAS DE LÍQUOR ...........41

3.8) REAÇÃO EM CADEIA POR POLIMERASE (PCR) …………..........41

3.8.1) VOLUMES E CONCENTRAÇÕES FINAIS ..........................42

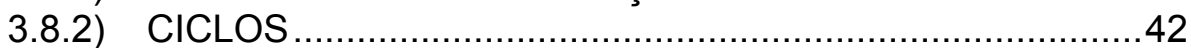

3.8.3) REVELAÇÃO DOS PRODUTOS DE AMPLIFICAÇÃO ........42

3.8.4) DIFERENCIAÇÃO ENTRE JCV E BKV ...............................43

3.8.5) SELEÇÃO DE CONTROLES POSITIVOS …………….......43

3.8.6) AVALIAÇÃO DA SENSIBILIDADE DO TESTE.....................44

3.8.7) CONTROLE NEGATIVO ................................................48

3.8.8) CONTROLE INTERNO ……………………………..... 49

3.8.9) AVALIAÇÃO DA TÉCNICA DE DETECÇÃO DO DNA DO

VJC NO LÍQÜOR, PARA DIAGNÓSTICO DA LEMP .........................50

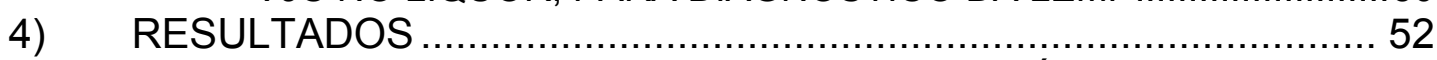

4.1) PACIENTES COM DNA-VJC POSITIVO NO LÍQUOR ......................56

4.2) PACIENTES COM DNA - VJC NEGATIVO NO LÍQUOR ……….......57

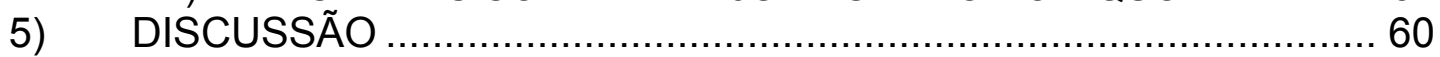

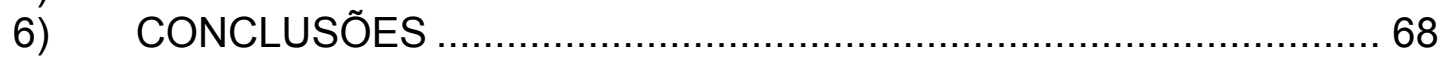

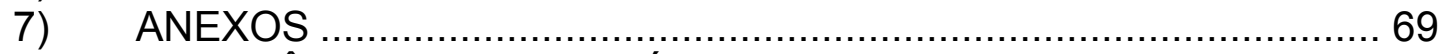

8) REFERÊNCIAS BIBLIOGRÁFICAS ........................................ 71 


\section{LISTA DE FIGURAS}

Figura 1 - Representação esquemática do vírus JC Mad1, demonstrando as regiões precoce e tardia do vírus, e, em evidência, a região regulatória. (JENSEN \& MAJOR; J. Leukocyte Biol 1999)

Figura 2: Foto de gel de agarose demonstrando a presença do fragmento de $173 \mathrm{pb}$ correspondente ao antígeno $\mathrm{T}$ do poliomavírus humano JC, inserido em vetor $p$ GEM-T Easy Vector 46

Figura 3: Foto de gel de agarose $2 \%$ demonstrando as diluições seriadas para titulação do inserto e a estimativa do limite de deteç̧ão da reação em cadeia por polimerase. 48

Figura 4: Foto de gel de agarose $2 \%$ marcado com brometo de etídio, contendo produtos de $173 \mathrm{pb}$ obtidos com os primers PEP ${ }_{1}$ e PEP 2 , linhas 1 a 11; linha 12, controle negativo. Nas extremidades, marcador de peso molecular de $100 \mathrm{pb}$. 54

Figura 5: Foto de gel de agarose $A 1000$ (Gibco BRL) 2\% marcado com Brometo de Etídio. Linhas 1, 2, 3, 4, 6, 8, 10 e 12: padrão característico do vírus JC (obtenção de dois fragmentos de 120 e 53 pb), após digestão com enzima de restrição Bam H1. Linhas 5, 7, 9: amostras sem digestão. Linha 11: controle negativo.

Figura 6: Contagem de células $\mathrm{TCD}_{4}+$ em relação à detecção do DNA do vírus JC através da reação em cadeia por polimerase 58 


\section{RESUMO}

FINK, M. C. D. S. Detecção do DNA do Poliomavirus humano JC em amostras de líquido cefalorraquidiano de pacientes com aids e lesões não expansivas de substância branca do sistema nervoso central.

Doenças neurológicas focais em pacientes com aids podem ser causadas por vários patógenos oportunistas. Dentre estas se inclui a encefalite por Toxoplasma gondii, os linfomas primários do sistema nervoso central causados pelo vírus Epstein-Barr, as encefalites virais (CMV, HSV, VZV) e a leucoencefalopatia multifocal progressiva (LEMP), causada pelo vírus JC (VJC).

O presente estudo teve por objetivos detectar o DNA do vírus JC em amostras de líquido cefalorraquidiano de pacientes com aids e lesões não expansivas de substância branca do SNC, bem como caracterizar esses pacientes com relação ao número de células $\mathrm{TCD}_{4}{ }^{+}$, sexo, idade e ocorrência de outros diagnósticos etiológicos.

A detecção do DNA do VJC foi realizada através da técnica de reação em cadeia por polimerase. O protocolo de PCR empregado, anteriormente descrito, utiliza um par de primers complementar à região precoce do vírus JC (antígeno T), resultando em um fragmento de 173 pb.

Todas as amostras positivas foram submetidas a etapa posterior de tipagem com enzima de restrição Bam $\mathrm{H} 1$, resultando em dois fragmentos menores (120 e 53 pb), característicos do vírus JC.

Com o intuito de estimar a sensibilidade da técnica empregada, um controle positivo qüantificável foi padronizado. O fragmento de $173 \mathrm{pb}$ amplificado de uma das amostras de líquor estudadas foi inserido em plasmídio, e o recombinante obtido foi quantificado através de espectrofotometria, titulado e submetido a PCR.

Através desta metodologia foi possível estimar que o teste é capaz de detectar a partir de 200 cópias/ $\mu$ l.

A especificidade do teste foi avaliada através da análise de amostras de líquor de pacientes com e sem aids e outros diagnósticos neurológicos, 
não compatíveis com LEMP. A pesquisa do DNA do vírus JC foi negativa em 119 de 120 amostras testadas, demonstrando uma especificidade de $99,17 \%$.

Foram incluídas no estudo 56 amostras de líquor de pacientes com lesão focal não expansiva de substância branca, compatível com LEMP, sendo positiva em 27/56 (48,2\%) e negativa em 29/56 (51,8\%).

Em 23 dos 29 (79,3\%) pacientes negativos para o vírus JC foi possível estabelecer um diagnóstico diferencial para os quadros encefalíticos: Toxoplasma gondii (nove casos), complexo cognitivo motor do HIV (CCMHIV) (cinco casos), tuberculose (três casos) e outros diagnósticos (oito casos).

Em seis pacientes DNA-VJC negativos não houve um diagnóstico final.

A caracterização da população avaliada, dividida em dois grupos, de acordo com o resultado da PCR (DNA-VJC positivo ou DNA-VJC negativo), não demonstrou diferença estatisticamente significante no que diz respeito ao sexo ou idade. No grupo de pacientes DNA-VJC positivos, o número de células $\mathrm{TCD}_{4}+$ foi significativamente mais baixo.

Os resultados do presente estudo demonstraram uma alta prevalência do DNA do VJC $(48,2 \%)$ nesse grupo de pacientes.

Foi possível concluir também que, em pacientes com aids e encefalite focal com lesões não expansivas de substância branca do sistema nervoso central, com PCR negativa para o VJC, é necessária uma investigação diagnóstica mais aprofundada já que a maioria desses casos apresenta outros agentes etiológicos, na maioria das vezes passíveis de tratamento. 


\section{SUMMARY}

FINK, M. C. D. S. Detection of human polyomavirus JC in cerebrospinal fluid samples from aids patients with non-expansive focal lesions of CNS white matter.

Focal neurological diseases in aids patients can be caused by a range of opportunistic pathogens such as Toxoplasma gondii, EBV-associated primary CNS lymphomas, viral encephalitis (CMV, HSV, VZV) and JC virus causing the progressive multifocal leukoencephalopathy (PML).

In the present study, we evaluated the detection of JC virus DNA in CSF samples from aids patients with white matter non-expansive lesions of CNS by polymerase chain reaction (PCR) and characterize this finding in relation to the number of TCD4+, age, gender, and other etiological diagnosis.

The primers used to amplify the $T$ antigen region of $\mathrm{JC}$ virus resulted in a fragment of 173 base pairs. Since JC virus harbor a BAM H1 restriction site in this region, digestion of the PCR product with the enzyme resulted in two fragments of 120 and 53 base pairs, characteristic of JC virus.

To estimate the sensitivity of the assay, the $173 \mathrm{bp}$ fragment obtained from one of the samples was inserted into a plasmid and the recombinant quantified by spectrophotometry. The sensitivity of the PCR was 200 copies / $\mu \mathrm{L}$.

The specificity of the assay was evaluated in CSF samples from patients with and without aids and other neurological conditions, not suggestive of PML. The PCR resulted negative in 119 of the 120 CSF samples tested showing a specificity of $99,17 \%$.

In 56 CSF samples from patients with neurological symptoms and radiological signs of PML, JC virus was detected in 27 (48.2\%) by PCR. In 23 of the remaining 29 patients $(79.3 \%)$ other neurological conditions were diagnosed: T. gondii encephalitis (9 cases), HIV encephalitis (5 cases), tuberculosis (3 cases) and other diagnosis (8 cases). In six patients no neurological disease diagnosis could be established. 
In the group of patients characterized as JC virus-DNA positive the mean number of TCD4+ was significantly lower as compared to the JC virus-DNA negative patients. No statistical difference was seen in relation to gender or age distribution between the two groups.

The results of the present study demonstrated a high prevalence of $\mathrm{JC}$ virus DNA $(48,2 \%)$ in patients with clinical and radiological signs of PML. We concluded that the polymerase chain reaction for JC-virus DNA detection can represent an advance in the diagnosis of PML. aids patients with nonexpansive focal lesions of CNS white matter and JC virus-DNA negative by PCR probably have other treatable neurological conditions that must be extensively investigated. 


\section{1) INTRODUÇÃO}

\section{1) HISTÓRICO:}

Infecções oportunistas do sistema nervoso central e alterações neurológicas associadas ao HIV surgem como complicadores em vários estágios da evolução da infecção. A incidência dessas infecções oportunistas aumenta no período tardio da aids, e podem ocorrer em cerca de $40 \%$ a $60 \%$ de todos os pacientes com aids (JANSSEN, 1997).

Doenças neurológicas focais podem ser causadas por vários patógenos oportunistas, podendo-se incluir, dentre estas, a encefalite pelo Toxoplasma gondii, os linfomas primários de sistema nervoso central relacionados ao vírus Epstein-Barr, as encefalites virais (CMV, VZV, HSV), os quadros de demência ocasionados pelo HIV e, finalmente, a leucoencefalopatia multifocal progressiva (LEMP), causada pelo vírus JC (VJC) (SKIEST et al, 2002).

Embora tenha sido descrita inicialmente em 1930 pelo neuropatologista alemão Hallervorden como "doença não classificável" (citado por BERGER, 1999), a LEMP foi claramente delineada como síndrome em 1958 por Astrom e col, com a apresentação de três casos de uma rara doença humana desmielinizante, denominada por eles de "leucoencefalopatia multifocal progressiva" (LEMP), que surge como uma complicação tardia de doenças neoplásicas extra-craniais, preferencialmente do tecido linfóide (ASTROM et al, 1958). 
A caracterização dessa doença foi feita com base nos achados histopatológicos característicos: desmielinização resultante da destruição dos oligodendrócitos, hipertrofia nuclear nos oligodendrócitos que apresentam densa basofilia e perda dos detalhes nucleares e, finalmente, hiperplasia dos astrócitos, que se apresentam como células gigantes de aspecto bizarro, semelhantes a células neoplásicas (ASTROM et al, 1958).

A etiologia da LEMP permaneceu incerta, embora a demonstração de corpúsculos de inclusão no núcleo dos oligodendrócitos infectados indicasse uma possível etiologia viral (CAVANAUGH et al, 1959, RICHARDSON, 1961).

Em 1967, Zu Rhein, com base nos achados da microscopia eletrônica, sugeriu que um poliomavirus poderia ser o responsável por essa doença (ZU RHEIN, 1967). Estudos subseqüentes foram realizados e a possível etiologia viral continuou sendo sugestiva, uma vez que a maioria dos casos era diagnosticada através da autópsia e sempre com base em evidências morfológicas no tecido fixado (RAUSING \& AXELSON, 1970). A confirmação inequívoca dessa hipótese ocorreu em 1971, quando Padgett e col conseguiram isolar o vírus em culturas celulares permissivas, constituídas por células da glia de fetos humanos, através da inoculação de extratos do tecido cerebral de um paciente portador de linfoma de Hodgkin que apresentava doença neurológica desmielinizante (PADGETT et al, 1971).

Como as iniciais desse paciente eram JC, estas passaram a referenciar o vírus. Esta primeira cepa do vírus JC foi identificada em 
Madison, Wisconsin, sendo, por esta razão, denominada de "protótipo Mad 1". (PADGETT et al, 1971)

A leucoencefalopatia multifocal progressiva era, inicialmente, uma doença rara, que ocorria em pacientes imunologicamente debilitados por doenças crônicas, doenças genéticas tais como a síndrome "Wiskott-Aldrich" (Katz et al, 1994) ou uso prolongado de drogas citotóxicas ou imunossupressoras (NAGASHIMA et al, 1981, KATZ et al, 1994). Desde sua identificação inicial por Astrom e col como uma complicação rara da doença de Hodgkin e leucemia linfocítica crônica, casos subseqüentes foram descritos, em pequeno número, em associação com outras leucemias e linfomas ou em pacientes submetidos à quimioterapia para tratamento de câncer ou ainda, recebendo terapia imunossupressora pós-transplante de órgãos (GRENLEE, 1998).

Com o surgimento e a evolução da epidemia de aids, entretanto, a epidemiologia dessa doença foi drasticamente alterada.

A primeira descrição da LEMP como complicador da aids foi feita em 1982, por Miller e col, em um paciente homossexual masculino, com deficiência na imunidade de células $T$ que, ao exame neurológico demonstrava nistagmo horizontal bilateral, alteração de sensibilidade em face e braço esquerdo, além de incoordenação e sensível diminuição da força muscular no mesmo braço. Estudos sorológicos desse paciente demonstravam infecções prévias por inúmeros microorganismos, inclusive o VJC, sem evidência de infecção ativa por nenhum deles. O exame do líquido cefalorraquidiano demonstrou parâmetros normais, exceto pela 
concentração de proteína. A tomografia computadorizada do cérebro demonstrou uma área de densidade diminuída no hemisfério cerebral esquerdo sem captação de contraste ou efeito de massa (MILLER et al, 1982)

A partir desse relato, seguiram-se vários outros envolvendo pacientes com aids e quadro clínico compatível com LEMP.

Em 1983, Snider e col analisaram um grupo de cinqüenta pacientes com aids e complicações neurológicas de naturezas diversas. Dois pacientes tiveram diagnóstico de LEMP através da tomografia computadorizada que demonstrava lesões hipodensas em hemisférios cerebrais, sendo a etiologia confirmada através da detecção do vírus em fragmento cerebral (SNIDER et al, 1983).

Casos esporádicos de leucoencefalopatia multifocal progressiva continuaram a ser descritos em pacientes com aids que apresentavam características semelhantes com relação ao quadro clínico e a contagem de células T (BEDRI et al 1983, KRUPP et al 1984, BLUM et al 1985). A prevalência estimada de LEMP, em 1991, entre os pacientes com aids, na região de San Francisco era de 0,3\% (GILLESPIE et al, 1991).

Pesquisa realizada por Berger e col no período de 1982 a 1987 encontrou resultados, com base nos achados histopatológicos e diagnóstico por imagem, sugestivos de uma prevalência de cerca de $4 \%$ de LEMP em pacientes com aids (BERGER et al, 1987).

A análise dos atestados de óbito realizada pelo CDC (Center for Disease Control and Prevention, USA), entre 1981 e 1990, encontrou 971 
casos de LEMP confirmados histopatologicamente $(0,72 \%)$ entre 135.644 indivíduos com aids (HOLMAN et al,1991).

Hoje, mesmo após a introdução da terapia anti-retroviral de alta eficácia (HAART), não se demonstra diferença significativa na incidência de LEMP entre a era pré HAART e a atual (ANTINORI et al, 2001). Estima-se, atualmente, que $5 \%$ das doenças neurológicas que ocorrem nos pacientes com aids sejam causadas pelo VJC, chegando a $10 \%$ nos exames histopatológicos, o que demonstra, indiretamente, a dificuldade no diagnóstico em vida (BERGER, 1998).

\section{2) CLASSIFICAÇÃO}

O agente etiológico responsável pela LEMP (JC), foi primeiramente classificado como membro do gênero Polyomavirus, pertencente à família Papovaviridae, segundo a primeira publicação do Comitê Internacional em Nomenclatura dos Vírus (CINV), juntamente com o segundo gênero desta família, composto pelos Papillomavirus (MELNICK et al, 1974).

Em 1973, um grupo de estudos em Papovaviridae pertencente ao CINV reconsiderou a nomenclatura dos gêneros, renomeando-os como Papovavirus $A$ (papilomavirus humanos e animais) e Papovavirus $B$ (poliomavirus humanos e animais). O vírus JC foi classificado no gênero Papovavirus $B$, juntamente com poliomavirus animais de diferentes espécies. (MELNICK e col, 1974).

Estudos realizados a partir de 1980 demonstraram diferenças entre os poliomavirus e os papilomavirus com relação aos tamanhos do capsídeo (45 
$\mathrm{nm}$ de diâmetro contra $55 \mathrm{~nm}$ ) e do genoma (cerca de 5000 pares de bases contra 8000 pares de bases) e quanto à sua organização genômica. (FIELDS, 2000).

Recentemente, o Comitê Internacional em Taxonomia dos Vírus reconheceu que os Polyomavirus devem compor uma família independente de vírus, a família Polyomaviridae. (FIELDS 2000, site ICTV).

\subsection{1) OUTROS POLIOMAVIRUS RELEVANTES EM DOENÇAS HUMANAS}

Além do vírus JC, um outro poliomavirus causador de doença humana foi identificado em 1971, a partir da urina de um paciente submetido a transplante renal que desenvolveu obstrução de ureter (GARDNER et al, 1971). Também neste caso, o vírus isolado recebeu as iniciais do paciente: BK.

Diversas patologias têm sido associadas ao vírus BK (VBK), como as nefrites túbulo intersticiais (ROSEN et al, 1983) e estenose de ureter em pacientes submetidos a transplante renal (HOGAN et al, 1980), doenças agudas do trato respiratório superior (demonstradas através do aumento dos títulos de lgG) (GOUDSMIT et al 1982), além da descrição de um caso de pneumonia intersticial em paciente receptor de células tronco (SANDLER et al, 1997).

NOORDA e VAN DILLEN (1977) demonstraram o envolvimento do vírus BK em síndromes neurológicas pós-doença respiratória, através do 
aumento de títulos de anticorpos presentes no soro deste pacientes (NOORDAA \& VAN DILLEN, 1977).

Síndromes causadas pelo VBK foram descritas, esporadicamente, em pacientes com aids, tais como pneumonites (CUBUKCU-DIMOPULO et al, 2000), encefalites (LESPRIT et al, 2001) e retinites (HEDQUIST et al, 1997).

Dentre as diversas patologias associadas ao VBK, a que merece maior atenção é a cistite hemorrágica, uma complicação freqüente dos transplantes de medula óssea alogênicos, que, por vezes, põe em risco a vida do paciente, e pode ocorrer em mais de $50 \%$ dos receptores de medula óssea (ARTHUR et al, 1986).

Juntamente com o adenovirus, o VBK é responsável pelo surgimento da cistite hemorrágica tardia (após 72 horas do regime de condicionamento), cujas incidência e gravidade podem variar de acordo com o grau de imunodepressão e o emprego de medidas profiláticas contra a doença do enxerto versus hospedeiro (CHILDS et al, 1998).

Além dos poliomavirus humanos, outros onze membros da família Polyomaviridae foram identificados, amplamente distribuídos entre diversas espécies animais (ratos, macacos, coelhos, pássaros, etc), contribuindo para a gênese de tumores nessas espécies (FIELD, 2000).

Dentre os poliomavirus animais, o de maior interesse clínico para os seres humanos é o vírus vacuolizante símio (SV 40).

A primeira descrição da infecção humana pelo SV 40 ocorreu através da contaminação das vacinas antipoliomielite produzidas em rim de macacos 
Rhesus, no período de 1955 a 1963, quando 10 milhões de crianças americanas foram expostas a esse vírus, sabidamente causador de tumores (FIELDS, 2000).

STRICKLER e col (1998), após 30 anos de acompanhamento, demonstraram que a exposição ao SV 40, através da vacinação, não estava associada a aumento significativo de qualquer um dos diversos tipos de tumor ocasionados por esse vírus (STRIKCLER et al, 1998). Outros estudos, entretanto, têm demonstrado a presença de seqüências genômicas do SV 40 em tumores humanos, especificamente mesoteliomas (CARBONE et al, 1994), osteossarcomas (CARBONE et al, 1996), ependiomas (LEDNICKY et al, 1995), tumores do plexo coróide (BERGSAGEL et al, 1992) e, recentemente adenomas pleomórficos de glândulas parótidas (MARTINELLI et al, 2002).

\section{3) ESTRUTURA GENÔMICA}

A análise genômica dos poliomavirus demonstra uma extensa similaridade genética entre eles; o VJC possui uma similaridade de $75 \%$ ao vírus BK e 69\% ao SV 40, o que sugere uma íntima relação evolucionária. (FRISQUE et al, 1984)

O JC é um vírus não envelopado de aproximadamente $40 \mathrm{~nm}$ que apresenta simetria icosaédrica e um pequeno genoma (5130 bp) composto por um DNA dupla fita, ligado a histonas celulares $\mathrm{H} 2 \mathrm{~A}, \mathrm{H} 2 \mathrm{~B}, \mathrm{H} 3$ e $\mathrm{H} 4$, na forma de cromatina (FRISQUE et al, 1984). 
O mapeamento físico inicial do VJC foi realizado através do emprego de enzimas de restrição (DEININGER et al, 1980), onde o ponto "zero" da replicação foi arbitrariamente definido como o sítio de restrição reconhecido pela enzima EcoR1, recebendo o nome de ori, a partir do qual o genoma é transcrito bi-direcionalmente (SOEDA et al, 1977). São determinadas, desta forma, regiões do genoma funcionalmente distintas, compostas por três domínios: a região precoce, por definição, a porção do genoma transcrita e expressa imediatamente após a entrada do vírus na célula, e que continua a ser expressa após o início da replicação do DNA viral (FIELDS, 2000), possui a mesma polaridade dos mRNAs precoces (DEININGER et al, 1980), cujos genes codificam as proteínas $\mathrm{T}$ grande e pequena (antígenos $\mathrm{T}, \mathrm{t}$ ); a região tardia que é responsável pela codificação das proteínas do capsídeo viral VP1, VP2 e VP3, a agnoproteína e, por fim, uma região não codificadora, composta pela origem da replicação (ponto zero), associada a elementos promoters/ enhancers que, juntos, são referidos como "região regulatória viral" (SOEDA et al, 1977, FRISQUE et al, 1984, RAJ e KHALILI, 1995).

O processo de replicação viral inicia-se pela expressão do antígeno $\mathrm{T}$, o que ocorre antes da replicação do DNA do vírus (SWEET et al, 2002).

Os antígenos $\mathrm{T}$ grandes são complexos multifuncionais compostos por fosfoproteínas, responsáveis por atividades enzimáticas diversas (proteinoquinases e ATPases) (HAND, 1981). Encontram-se ligados à região reguladora do genoma viral e dão início à replicação do DNA do vírus, além de estimular a síntese de DNA do hospedeiro, através do aumento da 
expressão das enzimas celulares associadas a esta síntese (HAND, 1981, FRISQUE et al, 1984). Assim, o antígeno T age como um regulador central do ciclo lítico viral (SWEET et al 2002). Além de desempenhar esta função reguladora, um experimento realizado por SMALL e col (1986), utilizando camundongos transgênicos, demonstrou que o antígeno T (precoce) do vírus JC é o responsável pela indução do processo de desmielinização, afetando a expressão dos genes de mielina pela interação com fatores de transcrição, MEF-1/ pur $\alpha$, responsáveis pela regulação da síntese da proteína básica de mielina (MBP) (SMALL et al, 1986). O antígeno t pequeno parece não desempenhar qualquer papel na multiplicação do vírus ou no surgimento de tumores no homem, porém, quando expresso em células de alguns roedores e primatas não humanos, é responsável pela transformação celular maligna (LONDON et al, 1978; WALKER et al, 1973).

As proteínas do capsídeo, cujos genes codificadores encontram-se na região tardia, se acumulam no interior do núcleo da célula infectada, associando-se ao DNA viral replicado, formando os vírions que vão lisar a célula hospedeira (GORDON et al, 2000). A proteína VP1, a maior de todas, é responsável pela ligação do vírus à membrana celular, além de possuir os epítopos responsáveis pela indução dos anticorpos e, finalmente possibilitar a tipagem das cepas do vírus JC. (STONER, 1986; JOBES, 1998).

Estudos realizados em poliomavirus murinos demonstraram que as duas outras proteínas que compõem o capsídeo (VP2 e VP3) interferem na liberação viral e que a interação da proteína VP1 com as proteínas VP2/3 
pode desempenhar um papel essencial no ciclo de vida do vírus e estrutura do capsídeo (BAROUCH et al, 1994).

A região regulatória é uma seqüência não codificadora, posicionada entre as regiões precoce e tardia do vírus, contendo a origem da replicação do DNA e os sinais para transcrição tardia e precoce (FRISQUE 1983; FRISQUE, 1984). Estudos utilizando mapeamento genômico do VJC por enzimas de restrição demonstraram a existência de diferentes variantes genéticas, não detectadas sorologicamente, mas que apresentam diferentes propriedades biológicas ocasionadas por alterações dessa região hipervariável ou regulatória (GRINELL et al, 1983).

Com base na estrutura da seqüência regulatória, também conhecida por região de controle transcricional (TCR), duas formas do vírus $\mathrm{JC}$, com diferentes propriedades biológicas, são reconhecidas: a forma arquetípica e a forma rearranjada (YOGO et al 1990, CIAPPI et al 1999).

A forma arquetípica é encontrada basicamente na urina, em indivíduos sadios e imunocomprometidos e sua região regulatória apresentase altamente conservada, ou com pequenas variações de nucleotídeos, consistindo em uma seqüência de 98 pares de bases, com uma inserção de 23 pares de bases rica em GC e uma segunda inserção de 66 pares de bases (YOGO et al 1990, MAJOR et al 1992, AGOSTINI et al 1996). Segundo YOGO e col, o arquétipo parece ser a forma circulante do vírus na população (YOGO et al, 1990).

Aparentemente, durante a replicação viral, rearranjos de seqüências ocorrem dentro da região regulatória do vírus tipo arquétipo, resultando 
numa nova forma, potencialmente mais ativa do vírus (ZOLTICH et al 1995, DANIEL et al, 1996).

A comparação de seqüências da região regulatória de um número de isolados do vírus $\mathrm{JC}$, revelou uma hipervariabilidade em sua organização estrutural. Estas variações incluem deleções e duplicações, que ocorrem em seqüências denominadas promoters/ enhancers, que funcionam como ativadores da transcrição de genes virais (FRISQUE, 1983).

A região regulatória da cepa Mad 1 do vírus JC, a primeira forma rearranjada do vírus isolada do tecido cerebral de um paciente com LEMP (PADGETT et al, 1971), é caracterizada pela presença de seqüências repetitivas com 98 pares de bases, (tandem repeat) cada uma contendo uma seqüência rica em A T (timina e adenina), os "TATA boxes" (KENNEY et al 1984, ZOLTICH et al 1995), adjacentes a um pentanucleotídio AGGGAAGGGA, responsável pela regulação da transcrição do promotor tardio do vírus (TADA et al 1991, CHANG et al 1994).

Postula-se que essas deleções ou duplicações que ocorrem na região regulatória do vírus tipo arquétipo dariam origem a um vírus com capacidade de replicação em células da glia (ZOLTICH et al 1995).

Experimentos "in vitro" demonstraram o acentuado tropismo do vírus JC "tipo LEMP" por células da glia (KENNEY et al 1984, KALILI et al, 1988; VACANTE et al, 1988), embora possa ser encontrado em linfócitos circulantes (TORNATORE et al 1992, CIAPPI et al 1999). Em um paciente com LEMP, pode-se encontrar estas duas formas, sendo o arquétipo encontrado na urina e o "tipo LEMP" ou rearranjado, no sistema nervoso 
central (MARTIN et al, 1985; SABATH et al, 2002). À região regulatória é atribuída, também, a capacidade de mudança entre os estados de infecção latente para lítica (JENSEN, 2001).

Em adição às proteínas estruturais existe uma outra denominada agnoproteína, cuja função permanece desconhecida. Um estudo realizado por SAFAK e col (2001) demonstrou, através de ensaios de cromatografia e imunoprecipitação, além de estudos funcionais, que a agnoproteína e o antígeno $\mathrm{T}$ interagem fisicamente e que a replicação do DNA pode ser regulada pela agnoproteína (SAFAK et al, 2001). 


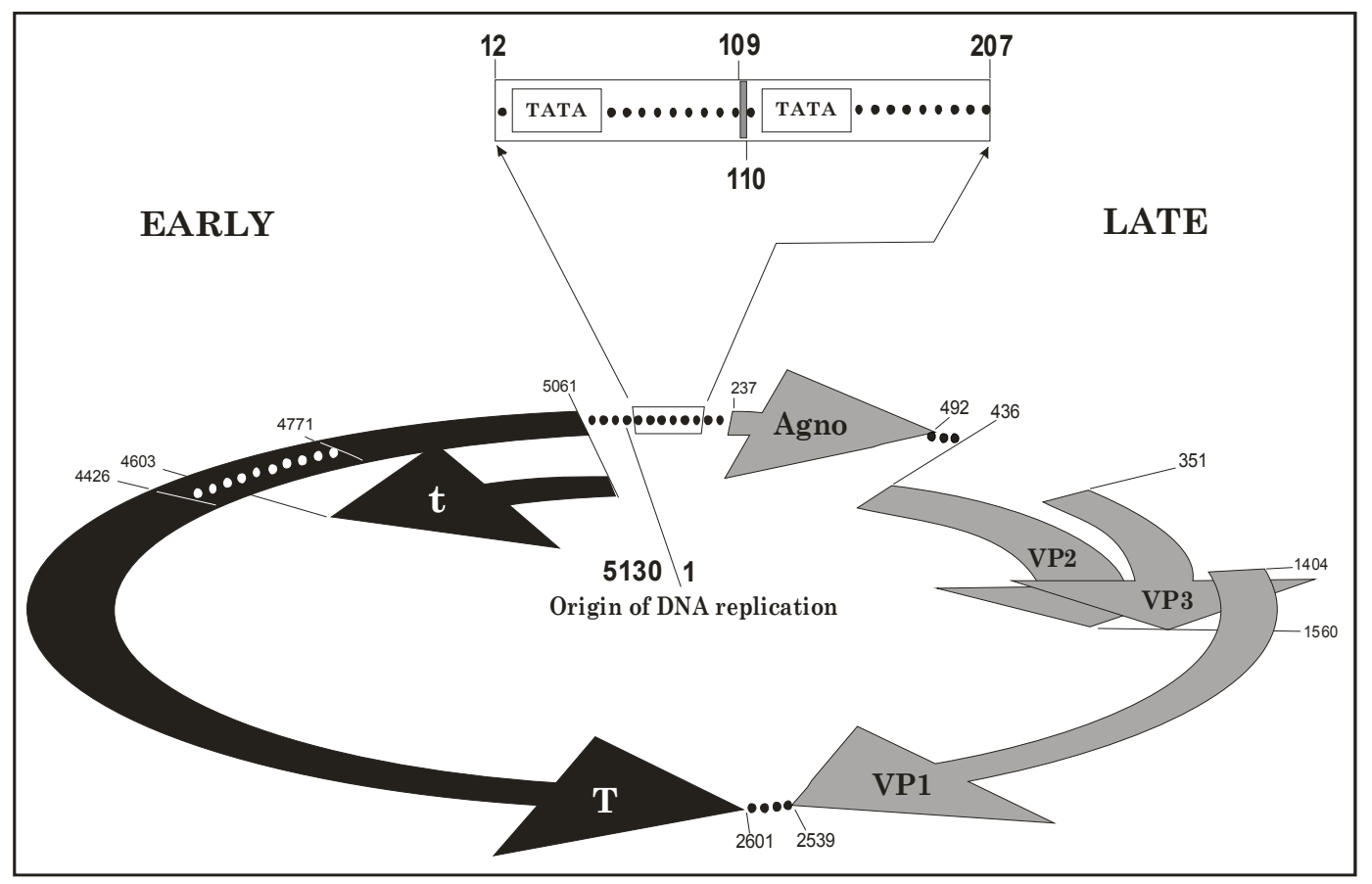

Figura 1 - Representação esquemática do vírus JC Mad1, demonstrando as regiões precoce e tardia do vírus, e, em evidência, a região regulatória. (JENSEN \& MAJOR; J. Leukocyte Biol 1999) 


\section{4) EPIDEMIOLOGIA}

\subsection{1) FORMAS DE TRANSMISSÃO DO VÍRUS}

Estudos soroepidemiológicos indicam que aproximadamente $70 \%$ da população humana é infectada com o poliomavirus humano JC, sem associação com qualquer quadro clínico. (GARDNER et al 1973, BROWN et al 1975, FLAEGSTAD et al 1988). Inquéritos soroepidemiológicos realizados na população geral, utilizando-se a técnica de inibição da hemaglutinação indicam que a soroconversão ocorre precocemente, ao redor de cinco a sete anos de idade (TAGUCHI et al 1982). A técnica de hemaglutinação utilizada para deteç̧ão de anticorpos demonstrou menores índices de positividade em crianças do que em adultos (CHANG et al 2002).

Esses estudos soroepidemiológicos são confirmados pelo encontro freqüente do vírus $\mathrm{JC}$ em urina e outros tecidos, em indivíduos da população geral. A prevalência da infecção pelo poliomavírus humano JC foi recentemente investigada na população de Taiwan por CHANG e col (2002), através da detecção do DNA viral na urina, empregando-se a reação em cadeia por polimerase. Os resultados demonstraram que a prevalência da virúria do JC foi menor em indivíduos jovens e maior em indivíduos idosos, chegando a 79,9\% em adultos maiores de setenta anos (CHANG et al 2002).

Permanece obscura, entretanto, a forma pela qual o vírus penetra no organismo humano, ou seja, de que forma ocorre a primoinfecção.

Em 1975, TAGUCHI e col relataram que a infecção pelo vírus BK é freqüente em gestantes e que o vírus poderia ser transmitido de forma 
congênita, já que evidenciaram presença de IgM no soro do cordão umbilical em 7,5 a 9,1\% dos recém-nascidos estudados (TAGUCHI et al 1975).

Contudo, embora alguns estudos sugiram que o vírus BK possa ser transmitido de forma congênita (TAGUCHI et al 1975), o mesmo, aparentemente, não ocorre com o vírus JC.

Estudo realizado por DANIEL e col, em 1981, com o intuito de averiguar a possibilidade de transmissão congênita do vírus JC, não encontrou evidências nesse sentido. Coletando amostras de sangue de gestantes soropositivas e soronegativas para o VJC, os pesquisadores observaram que, embora algumas gestantes apresentassem reativação do vírus (demonstrado através do aumento de quatro vezes o título de anticorpos e a presença de anticorpos neutralizantes), nenhuma criança apresentou anticorpos da classe IgM no soro do cordão (DANIEL et al 1981).

PIETROPAOLO e col (1998), tentando também demonstrar a transmissão vertical dos poliomavírus, pesquisaram a presença de duas regiões distintas do genoma dos vírus $\mathrm{BK}$ e JC (região regulatória e proteína VP1 do capsídeo) em materiais obtidos de autópsias realizadas em abortos (placenta, cérebro e tecido renal) e em placentas de mães com evolução gestacional normal, através da técnica de PCR. O DNA do VBK foi detectado em $80 \%$ das amostras de placenta e tecido cerebral e em $60 \%$ das amostras de rim, enquanto que nenhuma das amostras testadas para o DNA do VJC mostrou-se positiva. Estes resultados enfraqueceram consideravelmente a hipótese da transmissão vertical do vírus JC (PIETROPAOLO et al 1998). 
Ainda com o intuito de determinar a via de transmissão do vírus JC, KITAMURA e col (1994) pesquisaram a presença do DNA do vírus JC seus respectivos padrões de restrição em amostras de urina dos membros de oito famílias japonesas. Num total de vinte e uma crianças excretoras, quatorze apresentavam o mesmo sub-tipo excretado por seus pais ou mães, enquanto que sete delas excretavam sub-tipos diferentes. Esses achados sugerem que o VJC é transmitido horizontalmente, dentro e fora da família (Kitamura et al 1994). Utilizando enzimas de restrição, os autores classificaram os VJC urinários em dois subtipos, Cy e My, os quais são prevalentes na população japonesa (KITAMURA et al, 1994).

KUNITAKE e col (1995) realizaram pesquisa idêntica, utilizando como técnica o seqüenciamento do genoma do vírus. Selecionando famílias cujos pais e filhos excretavam o vírus JC por via urinária, confirmaram que as cepas excretadas pelos filhos eram, em $50 \%$ dos casos, idênticas às excretadas por seus pais ou mães. Já que a transmissão vertical não foi confirmada em outros estudos, estes dados sugerem que a infecção ocorre longitudinalmente, através de longa co-habitação e exposição freqüente ao vírus. Além disso, o fato de que $50 \%$ das cepas excretadas era diferente da mãe corrobora a idéia de que a transmissão vertical do vírus não é observada. Ressaltam, além disso, que para algumas crianças, a infecção se dava através do contato com o vírus JC excretado por outras pessoas tais como avós e babás (KUNITAKE et al, 1995). 
Por outro lado, a detecção do vírus JC em células estromais de amídalas e seus linfócitos associados, torna plausível que a primoinfecção pelo VJC possa ocorrer por via respiratória (MÔNACO et al, 1998).

Estudo realizado por RICCIARDIELLO e col (2000), demonstrou a presença de seqüências do VJC em amostras de tecido do trato gastrintestinal superior e inferior, em $75,8 \%$ dos pacientes estudados, indicando a alta prevalência do vírus no trato gastrintestinal de indivíduos imunocompetentes (RICCIARDIELLO et al 2000).

Três recentes estudos realizados por BOFILL-MAS e col em 2000 e 2001 demonstraram a presença de altas concentrações dos poliomavirus humanos JC e BK em esgotos urbanos de áreas geográficas distintas (Europa, Estados Unidos e África) (BOFILL-MAS et al 2000; BOFILL-MAS et al 2001a; BOFILL-MAS et al 2001b). Testes realizados a partir de amostras de esgoto infectadas experimentalmente com VJC urinário demonstraram a estabilidade das partículas virais por períodos de até noventa e dois dias, mesmo em presença de DNAses ou quando expostos a baixos níveis de $\mathrm{pH}$ (BOFILL-MAS et al 2001b). Segundo os autores, a detecção, especialmente do vírus JC, por sua especificidade como vírus humano, indica, além da poluição ambiental de origem antropogênica, a potencial transmissão através do trato gastrintestinal, aparentemente facilitada pela resistência do vírus a fatores ambientais (BOFILL-MAS et al 2001a) . 


\section{5) EPIDEMIOLOGIA MOLECULAR}

Diferentes genótipos do vírus JC foram descritos nos diferentes continentes. Esses genótipos são definidos com base no seqüenciamento nucleotídico do genoma viral, tomando-se como referência a seqüência de uma região de $610 \mathrm{pb}$ entre o final $3^{\prime}$ do gene VP1 e o gene codificador do antígeno T (AULT et al, 1992), uma região de 215 pb, próxima do final $5^{\prime}$ do gene VP1 (AGOSTINI et al, 1997), ou, finalmente a seqüência completa do genoma viral (JOBES et al, 1998).

A presença de tipos distintos do poliomavirus humano JC nas diferentes populações humanas sugere que este tenha se originado numa população ancestral, provavelmente na África, diferenciando-se no decorrer do tempo (JOBES et al, 2001). Migrações humanas, isolamentos geográficos, mecanismos de evolução e seleção de cepas virais contribuíram ao surgimento de pelo menos oito genótipos diferentes do vírus JC. Esses genótipos e seus subgrupos correlacionam-se com as populações humanas em diferentes regiões geográficas (JOBES et al, 2001). Os genótipos divergem em suas seqüências em cerca de 1 a 3\% (JOBES et al, 2001).

O tipo 1 é encontrado primariamente em indivíduos europeus e é amplamente distribuído nos Estados Unidos (FRISQUE et al 1984, AGOSTINI et al 1998, AGOSTINI et al 2001). O VJC tipo 2, possui dois subtipos e encontra-se predominantemente no nordeste da Ásia (AGOSTINI et al 1998 b). O vírus JC tipo 3 difere dos dois outros genótipos (1 e 2) em 
$2,2 \%$ e $1,3 \%$ respectivamente e pode ser encontrado na África oriental e em indivíduos afro- americanos (AGOSTINI et al 1997). O tipo 4, intimamente relacionado ao tipo 1 (diferença de apenas 1\%), é encontrado na região do Mediterrâneo (AGOSTINI et al 2001). O tipo 5, do qual apenas um isolado é conhecido, aparece como uma combinação de seqüências do tipo 6 com o tipo 2B (HATWELL \& SHARP, 2000). O tipo 6 é representativo das populações do oeste africano e África central (GUO et al 1996). O VJC tipo 7 é o genótipo mais freqüentemente encontrado ao sul e sudeste da China (GUO et al, 1998).

Finalmente, um novo genótipo do vírus JC (tipo 8), foi identificado em populações da Papua Nova Guiné e Micronésia (JOBES et al, 2001).

\section{6) PATOGENIA}

\subsection{1) LATÊNCIA E REATIVAÇÃO}

Aparentemente, a partir dos resultados dos vários estudos citados, a primoinfecção pelo vírus JC ocorre ainda na infância e, essa infecção primária parece ser seguida por um período de latência (COLEMAN et al, 1980) com a reativação ocorrendo sob condições especiais de imunodepressão. Em pacientes imunodeprimidos, demonstra-se a presença do vírus em vários órgãos, incluindo rins, baço e pulmões (MARKOWITZ et al, 1993; HOUFF et al, 1988; DÖRRIES et al, 1983), além da excreção urinária, demonstrada em $7 \%$ dos pacientes submetidos a transplante de medula óssea e $18 \%$ dos receptores de transplante renal (CHAISSON \& 
GRIFFFIN, 1990). Não havia, entretanto, nenhum estudo demonstrando a excreção do VJC em indivíduos imunocompetentes e sua conseqüente latência.

O primeiro estudo avaliando indivíduos normais foi realizado por COLEMAN e col, em 1980, através da análise de amostras de urina de uma população de 1235 gestantes, dentre as quais 40 (3,2\%), demonstravam alterações citológicas sugestivas de poliomavirus (COLEMAN et al, 1980).

Amostras de tecido retiradas de rins e cérebro de trinta indivíduos com diversas causas de morte foram analisadas por CHESTERS e col (1983). A presença de DNA do vírus JC foi detectada em $10 \%$ dessas amostras (CHESTERS et al, 1983).

Dois outros estudos realizados por KAHAN e col (1980) e COBB e col (1987) em pacientes diabéticos e em portadores de doenças geniturinárias, demonstraram excreção urinária dos poliomavirus (JC ou BK) em 2\% e 20\% respectivamente, sugerindo que a excreção dos poliomavirus humanos não está, necessariamente, associada a imunodeficiências (KAHAN et al, 1980;.COBB et al, 1987).

Em 1989, KITAMURA e col realizaram novo estudo reavaliando a excreção urinária do VJC em duas populações diferentes. A população I era composta por cento e vinte pacientes atendidos em clínicas urológicas, com idades variando entre zero e oitenta anos, e que apresentavam diversas patologias associadas ao sistema urinário. A população II, sem quaisquer sintomas urológicos, nem sob imunossupressão era composta por pacientes com idade entre 60 e 90 anos. As porcentagens de excreção foram bastante 
semelhantes entre os indivíduos das populações I e II com idade entre sessenta e noventa anos: $52,2 \%$ e $45,5 \%$ respectivamente. Este estudo demonstrou, também, a detecção do DNA do VJC em amostras seriadas desses pacientes, colhidas a intervalos de um a cinco meses, sugerindo que ocorrem reativações do vírus por longos períodos, provavelmente por toda a vida (KITAMURA et al, 1989).

Além da detecção do vírus em tecido renal, outros estudos demonstraram a presença do VJC em vários órgãos e tecidos, sendo, as células linfóides, um possível sítio de latência. O vírus JC foi primeiramente demonstrado em linfócitos pela detecção do DNA e proteínas do capsídio em células mononucleares de medula óssea de dois pacientes com LEMP (HOUFF et al, 1988). A partir de então, diversos estudos encontraram VJC em linfócitos isolados de medula óssea, sistema nervoso central e sangue periférico (TORNATORE et al, 1992; DUBOIS et al, 1997; MÔNACO et al, 1996).

TORNATORE e col (1992), utilizando a técnica de PCR, analisaram linfócitos periféricos de dezenove pacientes com LEMP comprovada através de biópsia cerebral, de vinte e seis pacientes soropositivos para HIV, sem sinais de leucoencefalopatia multifocal progressiva, e de um grupo de pacientes portadores de doença de Parkinson. O DNA do vírus JC foi encontrado nos linfócitos de $89 \%$ dos pacientes com LEMP, e de $38 \%$ dos pacientes HIV positivos sem LEMP. Não foi detectado material genômico do VJC em nenhum dos pacientes com doença de Parkinson, sugerindo que 
indivíduos imunocompetentes não apresentam o vírus em seus linfócitos periféricos (TORNATORE et al, 1992).

DUBOIS e col, em 1997, avaliaram a latência e reativação do vírus JC em sangue periférico em três diferentes grupos de indivíduos: setenta e dois pacientes HIV positivos, sete pacientes HIV positivos com LEMP e 50 doadores de sangue. Nesse estudo foi encontrado DNA do VJC em 40,3\% dos pacientes HIV positivos, sem sinal de LEMP, em cinco dos sete pacientes com LEMP e em $8 \%$ dos doadores de sangue (DUBOIS et al, 1997).

DOLEI e col, em estudo recente, demonstraram a presença do DNA do vírus $\mathrm{JC}$ em amostras de células mononucleares de sangue periférico de $0,9 \%$ de doadores de sangue e operadores dos centros de transfusão (DOLEl et al 2000).

Além da latência estabelecida nestes diversos sítios, um estudo realizado por MORI e col, em amostras de tecido cerebral de 10 pacientes idosos, imunocompetentes, que foram a óbito por diversas causas demonstrou, através de técnicas de hibridação in situ e imunohistoquímica, a presença do vírus JC em quatro desses indivíduos (MORI et al, 1990).

Através da análise de material de autópsia de 67 indivíduos que foram a óbito devido a doenças neurológicas (esclerose múltipla e doença de Hutington) ou sistêmicas, incluindo diversos tipos de tumores, ELSNER e DÖRRIES (1992) encontraram seqüências específicas de VJC em amostras de 19 pacientes, distribuídas por diferentes regiões do cérebro. Segundo os autores, com base nos achados desse estudo, a infecção pelo VJC está 
associada com a penetração sub-clínica do vírus no sistema nervoso central, podendo ocorrer reativação viral mediante imunodepressão (ELSNER \& DÖRRIES, 1992).

Utilizando primers e sondas, específicos para diferentes regiões do vírus, WHITE III e col analisaram amostras de rins e cérebro de dois diferentes grupos de pacientes: os que possuíam diagnóstico de LEMP e aqueles não LEMP. No grupo de pacientes com LEMP, foi possível detectar a presença de DNA do VJC em todas as amostras de tecido renal e cerebral, enquanto que, no grupo dos não LEMP, aproximadamente $50 \%$ dos pacientes apresentavam o vírus em tecido renal e $68 \%$ em fragmento cerebral (WHITE III et al, 1992).

QUINLIVAN e col também detectaram o VJC, através de PCR, em amostras de cérebro autopsiadas, em quatro de treze pacientes HIV positivos e em um de doze HIV negativos (QUINLIVAN et al, 1992).

Estudo semelhante realizado por VAGO e col demonstrou a presença de material genômico do vírus JC, através da técnica de PCR, em 100\% das amostras de tecido cerebral de pacientes HIV positivos com LEMP, em $44 \%$ dos pacientes HIV positivos sem LEMP e em $33 \%$ dos pacientes sem evidências clínicas de imunocomprometimento, que foram a óbito por doença cardíaca isquêmica e mal de Alzheimer (VAGO et al, 1996). 


\section{7) PATOGÊNESE DA LEUCOENCEFALOPATIA MULTIFOCAL PROGRESSIVA}

O mecanismo pelo qual o vírus JC induz a leucoencefalopatia multifocal progressiva em indivíduos imunocomprometidos ainda não está completamente esclarecido. Entretanto, diversos fatores parecem estar associados à patogênese da LEMP.

Certamente, um fator envolvido no desenvolvimento da LEMP é o status imunológico do paciente, já que essa doença geralmente ocorre em indivíduos que, por diversas razões, apresentam diminuição em sua resposta imune (GRINELL et al, 1983). Aparentemente, devido à persistência do vírus JC por longos períodos em um indivíduo, variações, especialmente da região regulatória (hipervariável) podem ocorrer in vivo, com amplificação e seleção de variantes ao longo do tempo (GRINELL et al, 1983; BERGER et al, 2001). Estas variações ou rearranjos da região regulatória ocorreriam devido à imunossupressão, levando a viremia do VJC e conseqüente disseminação hematogênica para o sistema nervoso central (KORALNICK et al, 1999).

Segundo DANIEL e col (2001), a região regulatória do vírus JC arquetípico, é menos suscetível a ativação da replicação do que o VJC tipo LEMP (DANIEL et al, 2001).

Estudo comparando diversos grupos de pacientes demonstrou a presença de rearranjos na região regulatória em todas as amostras de líquido cefalorraquidiano e leucócitos de sangue periférico dos pacientes com LEMP (CIAPPI et al, 1999). No caso do vírus tipo LEMP, esses 
rearranjos consistem na presença dos "tandem repeats" e outras estruturas ativadoras, responsáveis pela mudança da infecção da fase latente para lítica e o tropismo do vírus para células da glia (FRISQUE et al, 1983; KENNEY et al, 1984; KALILI et al, 1988; VACANTE et al, 1988).

A exemplo de outros patógenos virais humanos, a suscetibilidade de determinados tecidos para a infecção é definida, ao menos parcialmente, pela adsorção do vírus a receptores celulares específicos (SABATH \& MAJOR, 2002). A interação vírus-receptor desempenha um importante papel na determinação do tropismo viral e a patologia "tecido-específica" associada à infecção (LIU et al, 1998b)

A entrada do VJC na célula ocorre através da ligação do vírus a receptores celulares específicos: as glicoproteínas ligadas ao grupo $N$, contendo ácido siálico $\alpha_{2-6}$ terminal, que são compartilhadas com os outros poliomavirus, exceto o SV 40 (LIU et al, 1998a; LIU et al, 1998b; WEl et al, 2000). As partículas virais ligadas a esses receptores específicos serão interiorizadas em vesículas, através de um processo de endocitose clatrina dependente (PHO et al 2000).

Embora o VJC possa ligar-se a diferentes linhagens celulares e infectá-las, devido à ampla distribuição dos receptores específicos (SUZUKI e col, 2001), nem sempre ocorre a replicação viral, o que sugere a necessidade de outros fatores para essa replicação. KHALILI e col (1988) e AMEMIYA e col (1989) demonstraram a interação específica de fatores nucleares (NF-1 ou NF-1 like) com três sítios de ligação da região regulatória 
do vírus JC. Esses fatores são expressos em altos níveis nas células da glia (KHALILI et al, 1988; AMEMIYA et al, 1989).

A incidência significativamente maior de LEMP em pacientes com aids em relação a pacientes com outras doenças imunodepressoras sugere que a presença do vírus HIV-1 pode participar, direta ou indiretamente, da patogênese dessa doença. A presença do HIV em tecido cerebral apresenta características histológicas semelhantes à infecção pelo vírus JC, ou seja, alterações em substância branca, degeneração vacuolar, hipertrofia dos astrócitos e desmielinização (BERGER et al, 2001). Estudos recentes demonstram a presença do HIV em astrócitos e oligodendrócitos. A alta similaridade entre a LEMP e a encefalopatia causada pelo HIV sugere que a reativação do vírus JC é uma conseqüência da infecção pelo HIV, seja pela ação direta de fatores transativadores codificados pelo HIV ou secundariamente à depleção de células $\mathrm{TCD}_{4}+(\mathrm{BERGER}$ et al, 2001).

Alterações na barreira hemato-encefálica, facilitando a entrada do VJC no cérebro, carreado por linfócitos B, poderiam também contribuir para a patogênese da LEMP (POWER et al, 1993; BERGER et al, 2001).

Essas alterações, caracterizadas pelo aumento da permeabilidade vascular, ocorrem devido ao aumento da expressão de citocinas e moléculas de adesão no espaço perivascular, causado pelo HIV (POWER et al, 1993; BERGER et al, 2001).

Uma vez que as células da glia são produtivamente infectadas por ambos, VJC e HIV, a reativação do vírus JC pela superinfecção poderia 
representar um mecanismo "in vivo" da patogênese da leucoencefalopatia multifocal progressiva (BERGER et al, 2001).

Vários estudos demonstraram que o vírus HIV-1 codifica uma proteína trans-regulatória, Tat, que, através da interação com a proteína celular Pur $\alpha$ é capaz de aumentar consideravelmente os níveis de transcrição do HIV e do gene tardio do vírus JC, em células da glia (TADA et al, 1990; CHOWDHURRY et al, 1990; REMENICK et al, 1991).

Em condições normais, a expressão aumentada da Pur $\alpha$ é capaz de inibir a replicação iniciada na origem do vírus JC pelo antígeno T (DANIEL et al, 2001). Segundo o autor, em células da glia transfectadas experimentalmente com o HIV-1, a proteína Tat reverte essa inibição e potencializa a replicação do DNA do VJC. Ainda segundo o autor, a região regulatória do vírus JC tipo arquétipo foi menos suscetível a ativação da replicação do que o VJC tipo LEMP (DANIEL et al, 2001).

Tem-se tentado, também, investigar diferenças na suscetibilidade genética ao desenvolvimento da LEMP. Segundo HOLMAN e col (1991), parece haver uma maior prevalência de LEMP entre os indivíduos brancos, quando comparados a indivíduos afro-americanos (HOLMAN et al, 1991).

A possibilidade de diferentes genótipos do vírus JC estarem relacionados a patogênese da LEMP também foi investigada. FERRANTE e col (2001), analisaram várias amostras de VJC amplificados de amostras de líquor, linfócitos e urina de pacientes com aids, com e sem leucoencefalopatia multifocal progressiva, além de amostras de linfócitos e urina de indivíduos saudáveis. Apesar de se tratar de um grupo de pacientes 
provenientes da Europa (Itália), 52\% deles apresentavam VJC tipo 2 (característico da Ásia) no líquor (FERRANTE et al, 2001).

\section{8) MANIFESTAÇÕES CLÍNICAS}

A leucoencefalopatia multifocal progressiva produz lesões múltiplas na substância branca cerebral, ocasionando sinais e sintomas correlacionados ao sítio de envolvimento patológico (KRUPP et al, 1984).

A evolução da LEMP ocorre de forma sub-aguda, progressiva, evoluindo, geralmente para óbito entre dez dias e dezoito meses após o diagnóstico, com média de seis meses.

Um estudo realizado por BROOKS e WALKER, no qual foram revisados 109 casos patológica ou virologicamente testados, categorizou os sinais neurológicos e sintomas no início e durante a evolução da doença. Déficit visual foi o sinal mais comum, estando presente em 35 a $45 \%$ dos casos (BROOKS \& WALKER, 1984). A hemianopsia (perda de visão de metade do campo visual em cada olho), foi o problema visual mais encontrado, enquanto que 6 a $8 \%$ dos pacientes apresentavam-se corticalmente cegos no momento do diagnóstico, indicando patologia occipital (BROOKS \& WALKER, 1984). Fraqueza motora apresentou-se como sinal inicial em 25 a $33 \%$ dos casos, embora, no momento do diagnóstico, quase todos os pacientes apresentassem hemiparesia ou hemiplegia (BROOKS \& WALKER, 1984). 
Alterações mentais, as quais incluem mudança de personalidade, perda de memória, instabilidade emocional e franca demência mostraram-se presentes em aproximadamente um terço dos casos (BROOKS \& WALKER, 1984).

Estas manifestações clínicas foram encontradas, também, por BERGER e col (1987) numa série de 28 pacientes, além de outros sintomas que indicam envolvimento da substância branca do cerebelo e tronco cerebral tais como ataxia, dismetria e disartria (BERGER et al, 1987).

Outros sinais e sintomas associados a LEMP incluem dores de cabeça, vertigens, déficits sensoriais, parkinsonismo e afasias (BERGER et al, 1987).

\subsection{1) MÉTODOS DIAGNÓSTICOS DE NEUROIMAGEM}

A neuroimagem é o recurso diagnóstico mais utilizado na investigação de um paciente com LEMP.

$\mathrm{Na}$ tomografia computadorizada de crânio, as lesões desmielinizantes aparecem como hipodensidades sub-corticais com uma propensão para a área parieto-occipital, respeitando a junção das substâncias cinza e branca, sem seguir a distribuição vascular (CHAISSON \& GRIFFIN, 1990; MAJOR et al, 1992). Mostram-se assimétricas, sem efeito de massa e sem captação de contraste (CHAISSON \& GRIFFIN, 1990, MAJOR et al, 1992).

No início do quadro da LEMP, as imagens cerebrais obtidas através da tomografia computadorizada revelam alterações sutis, desproporcionais 
aos sinais e sintomas clínicos, caracterizando a dissociação clinicoradiológica (KRUPP et al, 1985). A alteração clinico-radiológica é uma característica não específica da apresentação da LEMP. Talvez isso ocorra porque pequenos focos de desmielinização produzem sintomas clínicos precoces, aparecendo na tomografia computadorizada de crânio apenas quando se tornam confluentes e mais intensos já com comprometimento axonal (KRUPP et al, 1985).

Na maioria dos casos ocorrem múltiplas lesões no sistema nervoso central, sendo que $10 \%$ dos casos apresentam uma única lesão cerebelar (KRUPP et al, 1985).

A presença de áreas de menor densidade na substância branca, sem efeito de massa, sem realce em fase contrastada, auxilia a distinção de lesões tumorais, granulomas e outras infecções (KRUPP et al, 1985).

A Ressonância Nuclear Magnética (RNM) é mais sensível que a Tomografia Computadorizada de Crânio (CT) com relação a identificação da extensão do acometimento nervoso e o número de lesões, apresentando alterações características em comparação à substância branca ao redor, demonstrando, ocasionalmente, a patologia onde a tomografia computadorizada de crânio é normal (MAJOR et al, 1992; WHITEMAN et al, 1993). 


\section{9) DIAGNÓSTICO LABORATORIAL E TRATAMENTO}

O diagnóstico da LEMP considerado definitivo consiste na detecção do agente etiológico em tecido cerebral (reação padrão ouro) (GILLESPIE, 1991).

A presença dos vírus $\mathrm{JC}$ em tecido cerebral pode ser comprovada através de diversas técnicas, tais como a microscopia eletrônica (ZU RHEIN , 1965), ou através do isolamento viral em culturas celulares permissivas, que consistem em células gliais fetais enriquecidas em espongioblastos (precursores celulares dos oligodendrócitos), as células produtoras de mielina no sistema nervoso central (CHANG et al, 1994).

Técnicas imunohistoquímicas podem também ser utilizadas, demonstrando-se a presença de antígenos específicos utilizando-se anticorpos monoclonais (BERGER, 1993) ou, ainda, demonstrando-se a presença de marcadores virais em tecido cerebral através de sondas de DNA marcadas (hibridação in situ) (AKSAMIT, 1986).

A alta invasividade destas técnicas, entretanto, torna difícil seu emprego para obtenção de um diagnóstico definitivo. GILDENBERG e col (2000) demonstraram, em duzentas e cinqüenta biópsias cerebrais, a ocorrência de complicações pós-cirúrgicas em 12\% dos pacientes, principalmente sangramento cerebral, sendo que destes, $9 \%$ evoluíram para óbito (GILDENBERG et al, 2000).

O diagnóstico é, então, realizado presuntivamente, através da associação entre achados clínicos característicos e tomografia 
computadorizada de crânio ou, quando disponível, a ressonância nuclear magnética, caracterizando a doença como "possível LEMP”. (GILLESPIE, 1991).

Sendo assim, a utilização de outras técnicas diagnósticas menos invasivas foram pesquisadas e, entre elas, o emprego da reação em cadeia por polimerase em líquido cefalorraquidiano. Diversos estudos, ao longo dos anos, vêm sendo realizados com o objetivo de demonstrar a aplicabilidade da técnica de PCR na detecção do DNA do VJC em amostras de líquor, em substituição à biópsia cerebral.

ARTHUR e col (1989) demonstraram a detecção do DNA dos poliomavirus humanos JC e BK em diferentes amostras clínicas (urina e tecido cerebral parafinado), amplificando uma região do genoma comum a ambos os vírus (antígeno T), utilizando um único par de primers (ARTHUR et al, 1989).

MORET e col (1993), colheram amostras de líquor e tecido cerebral de 12 pacientes com sinais clínicos compatíveis com LEMP, submetendo-as à amplificação do DNA do VJC por reação em cadeia por polimerase. Os resultados mostraram-se positivos em nove dos doze pacientes, tanto no líquor quanto no fragmento cerebral, demonstrando uma correlação de $100 \%$ entre os dois materiais clínicos (MORET et al,1993). Em outro estudo, Gibson e col detectaram, através da PCR, DNA do vírus JC em amostras de líquor em 10 de 13 pacientes com diagnóstico de LEMP confirmado histologicamente em tecido cerebral (GIBSON et al, 1993). 
WEBER e col (1994) encontraram uma grande variação quanto à sensibilidade da técnica $(43 \%$ a $82 \%)$. Esta diferença ocorreu devido ao emprego de primers complementares a diferentes regiões do genoma. A especificidade da técnica, entretanto, foi de 100\% (WEBER et al, 1994).

Analisando amostras de líquor de 26 pacientes McGUIRE e col encontraram, através da PCR, positividade em 24 pacientes. Destes, oito possuíam também amostras de tecido, que se mostraram positivas para o vírus JC (McGUIRE et al, 1995).

Dois outros grupos analisaram o emprego da reação em cadeia por polimerase como ferramenta diagnóstica para a detecção do DNA do vírus JC em amostras de líquor: FONG e col analisaram amostras de 23 pacientes com quadro clínico de LEMP confirmados por biópsia ou autópsia e encontraram positividade em 17 amostras, demonstrando uma sensibilidade de 73,9\%. Grupos controles de pacientes HIV positivos com diversos quadros neurológicos foram também analisados, observando-se positividade em dois deles, o que demonstra uma especificidade de 95,8\% (FONG et al, 1995).

HAMMARIN e col (1996) avaliaram a especificidade do método analisando 236 amostras de líquor de 212 pacientes com doenças do sistema nervoso central, dos quais 128 pacientes eram HIV positivos. O DNA do vírus JC foi amplificado em 14 deles (11\%), todos com quadro clínico-radiológico característico de LEMP. Em quatro destes pacientes foi feita a confirmação etiológica através da autópsia. Entre 84 pacientes HIV negativos, seis $(7 \%)$ possuíam DNA do vírus JC no líquor. Todos eles 
apresentavam imunodepressão, causada por outros fatores (linfomas, uso de drogas citotóxicas, etc), confirmando a ocorrência de LEMP em indivíduos com outros quadros de imunodepressão, que não a aids (HAMMARIN et al, 1996).

A especificidade da PCR foi também analisada por BOGDANOVIC e col (1998), realizando a reação em cadeia por polimerase para o vírus JC em 58 amostras de líquor de pacientes com diferentes quadros neurológicos (encefalites por HSV, meningites por enterovírus e outras meningites). A PCR mostrou-se positiva apenas nas amostras de pacientes com quadro clínico sugestivo de LEMP (BOGDANOVIC et al, 1998).

CINQUE e col demonstraram a aplicabilidade da técnica de PCR em amostras de líquido cefalorraquidiano de pacientes com aids e diversas doenças do sistema nervoso central, tais como linfomas, toxoplasmose, tuberculose, LEMP e encefalites por HSV e CMV. Os autores encontraram, na PCR para o vírus JC, sensibilidade variável entre 72 e $100 \%$ e especificidade entre 92 e 100\% (CINQUE et al, 1998).

As altas sensibilidade e especificidade da técnica de PCR em líquor foram demonstradas, também, por KORALNIK e col, com a detecção do DNA do vírus JC em 10 de 11 pacientes com evidências clínico-radiológicas de LEMP. Além da detecção, os autores determinaram a carga viral no líquido cefalorraquidiano, associando altas cargas virais com pior prognóstico em pacientes recebendo terapia anti-retroviral (KORALNIK et al, 1999). 
Com a introdução do esquema antiretroviral de alta potência (HAART) uma nova utilização foi encontrada para a PCR, para monitoramento dos pacientes quanto à presença e o "clearence" do DNA viral no líquor (MATSIOTA-BERNARD et al, 1997; CINQUE et al, 1998, DE VIEDMA et al, 1999).

Apesar da dramática diminuição nos índices de mortalidade e incidência de outras infecções oportunistas, devido ao uso da terapia HAART (PALELLA, 1998), a leucoencefalopatia multifocal progressiva é, ainda hoje, uma patologia de prognóstico sombrio, especialmente para aqueles que apresentam uma alta carga viral de JC no líquor ou, ainda, baixo número de células TCD4+ no sangue periférico (DE LUCA et al, 2000; TAOUFIK et al, 2000). Nesses casos, o emprego da terapia HAART associada a novas drogas com ação contra o JC, pode exercer um controle mais efetivo sobre a replicação do vírus, com melhora do quadro clínico e tempo de sobrevida do paciente (DE LUCA et al, 2000).

Algumas drogas já testadas, como a citarabina e a alfainterferona mostraram-se ineficazes contra o VJC. (TRUCHIS et al, 1993; TUBRIDY et al, 2000)

Atualmente, o cidofovir, droga aprovada pelo FDA (Food and Drug Administration), que é um agente antiviral com ampla atividade contra a família Herpesviridae, e vem sendo utilizado no tratamento da retinite por citomegalovírus, parece atuar, surpreendentemente, como potente droga antipoliomavirus "in vitro" (RAZONABLE et al, 2001). 
Embora não existam muitos ensaios clínicos e o número de pacientes em que a droga foi utilizada seja pequeno, alguns relatos vêm sendo feitos, nos quais se demonstra melhora ou estabilização do quadro clínico e aumento da sobrevida dos pacientes com LEMP quando em uso da terapia HAART associada ao cidofovir (DE LUCA et al, 1999; DE LUCA et al, 2000, RAZONABLE et al, 2001; CAMPOS et al, 2002).

A disponibilidade de drogas com potencial ação terapêutica sobre a LEMP reforça a necessidade de padronizações de técnicas diagnósticas rápidas para detecção do vírus JC no sistema nervoso central.

Dessa forma, a associação dos achados clínico-radiológicos a uma técnica diagnóstica pouco invasiva, específica e sensível como a PCR e a conseqüente detecção do DNA do vírus JC no líquor poderia servir como técnica diagnóstica rápida, que prescinda da biópsia cerebral (ANTINORI et al,1997). 
2) OBJETIVOS

1. Avaliar a prevalência do DNA do vírus JC no líquor de pacientes com aids e lesões não expansivas de substância branca do sistema nervoso central, compatíveis com LEMP, através da técnica de reação em cadeia por polimerase (PCR).

2. Caracterizar os casos com DNA VJC e os casos sem DNA VJC no líquor em relação à quantificação de células TCD 4+, idade, sexo e ocorrência de outros diagnósticos neurológicos. 
3) CASUísticA E MÉTOdOS

3.1) DESENHO DO ESTUDO

Estudo corte transversal, onde foi pesquisada a presença de DNA do poliomavirus humano $\mathrm{JC}$ em amostras de líquor coletadas de pacientes com aids apresentando encefalite focal e lesões não expansivas de substância branca do sistema nervoso central.

\section{2) DEFINIÇÃO DE CASO}

Pacientes com aids e lesão focal de sistema nervoso central, com imagem tomográfica de lesão não expansiva de substância branca.

\section{3) CRITÉRIOS DE INCLUSÃO}

Foram incluídas no estudo amostras de líquor colhidas na fase aguda da doença.

\section{4) CRITÉRIOS DE EXCLUSÃO}

As amostras de líquor que apresentavam volume insuficiente para a execução da PCR, ou amostras provenientes de pacientes sem avaliação neurorradiológica foram excluídas do estudo. 


\section{5) ASPECTOS ÉTICOS}

O projeto foi aprovado pelos comitês de ética das instituições envolvidas (anexo 1). Não foi obtido o termo de consentimento livre e esclarecido porque foram utilizadas somente amostras de líquor que haviam sido colhidas previamente, para elucidação diagnóstica, por indicação exclusivamente clínica do médico responsável. Estas amostras encontravam-se armazenadas a $-20^{\circ} \mathrm{C}$ nos laboratórios de origem.

Foi mantido o sigilo em relação à identidade dos pacientes.

\section{6) CASUÍSTICA}

Foram incluídos cinqüenta e seis pacientes com aids, diagnosticados segundo os critérios de definição do Ministério da Saúde e CDC (MMWR, 1992) e quadro clínico de encefalopatia focal e ausência de lesões expansivas de substância branca na tomografia computadorizada de crânio. Os pacientes foram atendidos nas Instituições participantes do projeto, a saber: Instituto de Infectologia Emílio Ribas (IIER) e Hospital das Clínicas da Faculdade de Medicina da Universidade de São Paulo.

\section{7) MÉTODOS LABORATORIAIS}

\subsection{1) COLETA DE LÍQÜOR}

As amostras foram coletadas pelo médico que assiste o paciente na rotina de investigação do quadro neurológico, e processadas no Laboratório de Virologia do Instituto de Medicina Tropical da Universidade de São Paulo, 
LIM 52 do Hospital das Clínicas da Faculdade de Medicina da Universidade de São Paulo.

\subsection{2) PROCESSAMENTO DAS AMOSTRAS DE LÍQUOR}

As amostras foram inspecionadas quanto à presença de sangue. Em casos positivos, o material foi submetido à centrifugação por 5 minutos a 1500 rpm para a formação do botão de hemácias, sendo retirado o sobrenadante e transferido para novo tubo.

Nos casos em que as amostras apresentaram sinais de hemólise, a extração foi realizada segundo a técnica de fenol-clorofórmio para eliminar quaisquer traços de hemoglobina, que funciona como um potente inibidor da amplificação do DNA viral (Al-Soud et al, 2001).

Das amostras sem hemólise ou hemácias, $100 \mu \mathrm{l}$ foram retirados, colocados em tubos Eppendorf, submetidos à fervura por dez minutos e centrifugados por $5 \mathrm{~min} / 1500 \mathrm{rpm}$ a $4^{\circ} \mathrm{C}$, para extração do DNA.

\section{8) REAÇÃO EM CADEIA POR POLIMERASE (PCR)}

A detecção do DNA viral presente nas amostras de líquor desses pacientes foi feita através da reação em cadeia por polimerase. O protocolo de amplificação empregado, descrito anteriormente por ARTHUR e col (1989), utiliza um par de "primers" complementares a região precoce do genoma dos poliomavirus humanos (antígeno T), comum aos vírus JC e BK: PEP1 - $\quad$ AGTCTTTAGGGTCTTCTACC e PEP2 GGTGCCAACCTATGGAACAG. 


\subsection{1) VOLUMES E CONCENTRAÇÕES FINAIS}

A seqüência alvo foi amplificada numa reação com volume final de $50 \mu \mathrm{l}$, contendo $10 \mu \mathrm{l}$ da amostra, tampão $10 \mathrm{X}$ (50 mM de $\mathrm{KCl}, 10 \mathrm{mM}$ de tris), dNTPs $200 \mu \mathrm{M}$, primer $0,5 \mu \mathrm{M}$ cada, $\mathrm{MgCl}_{2} 1,5 \mathrm{mM}$, Taq polimerase 2,5 $\mathrm{U} /$ reação.

\subsection{2) CICLOS}

Os tubos de reação contendo a amostra e a mistura de reagentes foram submetidos a 40 ciclos de amplificação em termociclador Perkin Elmer PTC 2400, como se segue: 1,5 min a $94^{\circ} \mathrm{C}$ para denaturação do DNA; 1,5 min a $55^{\circ} \mathrm{C}$ para anelamento dos primers e 2 min a $72^{\circ} \mathrm{C}$ para extensão da seqüência. Uma etapa inicial de 10 min para denaturação foi incluída, além de uma extensão final a $72^{\circ} \mathrm{C}$ por sete minutos. A sensibilidade do teste, descrita pelo autor, é de cem cópias do vírus JC e dez cópias do vírus BK.

\subsection{3) REVELAÇÃO DOS PRODUTOS DE AMPLIFICAÇÃO}

De cada tubo de reação foram retirados $10 \mu$ de amostra e misturados a $2 \mu \mathrm{l}$ de tampão de amostra $\left(20 \mathrm{~g}\right.$ de Ficoll, $60 \mathrm{ml} \mathrm{de} \mathrm{H}_{2} \mathrm{O}, 20 \mathrm{ml}$ de EDTA 0,5 M e 0,25 g de Xileno Cianol). Esta mistura foi aplicada em gel de agarose 2\% (A 1000, Gibco), diluído em TAE (tris-acetato-edta) contendo 0,8 $\mathrm{mg} / \mathrm{ml}$ de brometo de etídeo e, submetida a corrente de $100 \mathrm{~V}$ para eletroforese. O tampão utilizado para eletroforese também foi o TAE.

Após a eletroforese, os produtos de amplificação resultantes, no tamanho de 173 pares de bases, foram visualizados por transiluminação do 
gel por raios ultravioleta. O registro fotográfico foi feito através do sistema “Ultra-Lum” (Ultra-Lum Incorporation, Carson, Califórnia).

\subsection{4) DIFERENCIAÇÃO ENTRE JCV E BKV}

Por se tratar de um par de primers complementar a uma região altamente conservada entre os vírus $\mathrm{JC}$ e $\mathrm{BK}$, as amostras que se revelaram positivas passaram por etapa posterior, onde a diferenciação entre os vírus foi realizada através da digestão do produto amplificado com a enzima de restrição Bam H1. O fragmento do VJC foi clivado em dois outros menores com 120 e 53 pares de bases, (Arthur R, 1989), sendo possível diferenciá-lo do VBK, já que este não possui sítio de clivagem para essa enzima.

\subsection{5) SELEÇÃO DE CONTROLES POSITIVOS}

A técnica de PCR acima descrita foi inicialmente empregada para diagnóstico laboratorial de LEMP, sem que houvesse a disponibilidade de um DNA comercial quantificável, que pudesse ser utilizado como padrão positivo da reação.

Por essa razão, as amostras de líquor de pacientes com quadro clínico e diagnóstico por imagem sugestivos de LEMP foram sistematicamente testadas no laboratório. Uma das amostras que se revelou positiva, apresentando um produto do tamanho esperado (173 pb) e com sítio de clivagem para a enzima Bam H1 (resultando em dois fragmentos menores de 120 pb e 53 pb), foi enviada para realização do seqüenciamento genômico na empresa "Genomic Engenharia Molecular" (São Paulo) e a seqüência obtida foi submetida a um alinhamento de 
nucleotídeos através do gerenciador de banco de dados BLAST-n (http://www.ncbi.nlm.nih.gov/blast/Blast.cgi), número de submissão RID: 1065351073-8404-3222225.BLASTQ3, de nove de abril de 2003. A análise da seqüência revelou tratar-se realmente do genoma do vírus JC demonstrando a conseqüente especificidade do produto obtido.

Esta amostra, devidamente seqüenciada, foi utilizada como controle positivo nas reações posteriores.

\subsection{6) AVALIAÇÃO DA SENSIBILIDADE DO TESTE}

Uma segunda etapa na padronização da PCR consistiu na obtenção de um padrão quantificável possibilitando, assim, uma estimativa da sensibilidade do teste. Para tanto, foi realizada a clonagem, em plasmídio, do produto de PCR de uma das amostras, pela equipe coordenada pelo Prof. Dr. Paulo Cotrim, do Laboratório de Soroepidemiologia, setor de Biologia Molecular, do Instituto de Medicina Tropical de São Paulo.

Como inserto, foi utilizado um fragmento amplificado de amostra clínica diferente da anteriormente seqüenciada. O DNA foi purificado e através da enzima T4 DNA ligase foi ligado ao vetor (pGEM-T vector system).

Após um período de incubação $\left(15^{\circ} \mathrm{C}\right.$ por 3 horas), foi realizada a transformação em células altamente competentes, em colônias de $E$. coli DH $5 \alpha$ semeadas em meio LB a $37^{\circ} \mathrm{C}$, sob agitação constante, observando-se a turvação do meio. A esse meio de cultura foi adicionado Xgal, que se liga apenas às colônias de bactérias onde não ocorreu a ligação do inserto, alterando a cor das colônias (azuis). As colônias foram, então, plaqueadas e 
observou-se o crescimento de colônias brancas, indicando a possível ligação do inserto com o vetor, e colônias azuis, onde não ocorreu a ligação do inserto.

As colônias brancas isoladas foram semeadas em meio líquido para crescimento e extração do DNA. O DNA extraído foi submetido à digestão enzimática para linearização do plasmídeo (enzimas Apa e Ssc1) e, após a realização de eletroforese em gel de agarose, observamos a presença de duas bandas com tamanhos correspondentes ao vetor (3.000 pb) e ao inserto (173 pb).

O DNA recombinante obtido foi seqüenciado e titulado, para estimativa da sensibilidade do teste.

A demonstração da inserção encontra-se na figura 2. 


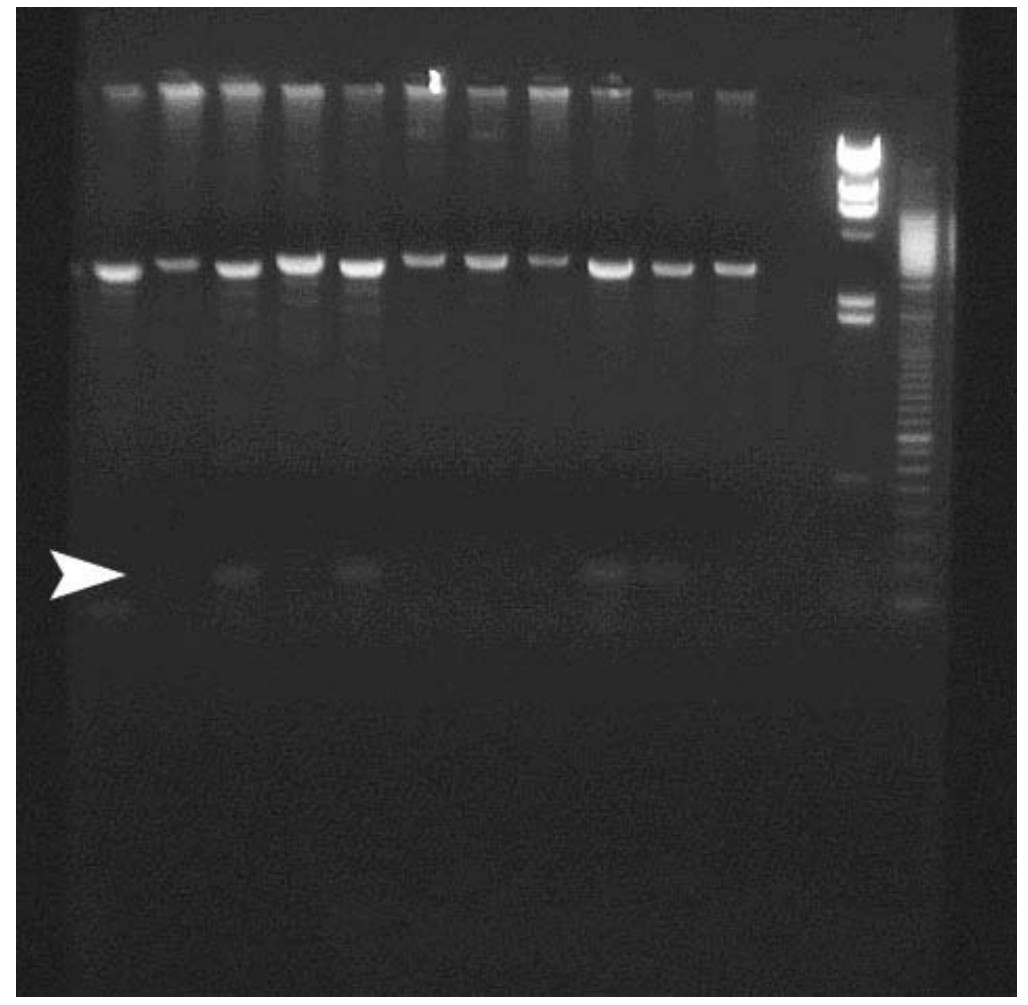

Figura 2: Foto de gel de agarose demonstrando a presença do fragmento de 173 pb correspondente ao antígeno $\mathrm{T}$ do poliomavírus humano $\mathrm{JC}$, inserido em vetor $\mathrm{p}$ GEM-T Easy Vector

A fim de determinarmos a sensibilidade da reação, ou seja, seu limite de detecção, duas diferentes quantificações do DNA recombinante obtido foram realizadas: uma através de espectrofotometria e a outra através da comparação da intensidade da banda obtida com um padrão comercial (Low DNA Mass Ladder, Life Technologies).

Através da espectrofotometria demonstramos a concentração de 100 ng de DNA e, através do Low DNA Mass Ladder, obtivemos uma concentração de 50 ng. 
A partir destas quantificações, diluições seriadas foram feitas, levando-nos a limites de detecção de 280 e 140 cópias, respectivamente.

Sensibilidade semelhante (aproximadamente 200 cópias de vírus) foi encontrada por De Luca e col (1996), utilizando o mesmo par de primers e as mesmas condições de ciclagem.

A titulação do DNA de VJC obtido encontra-se demonstrada na figura 3. 

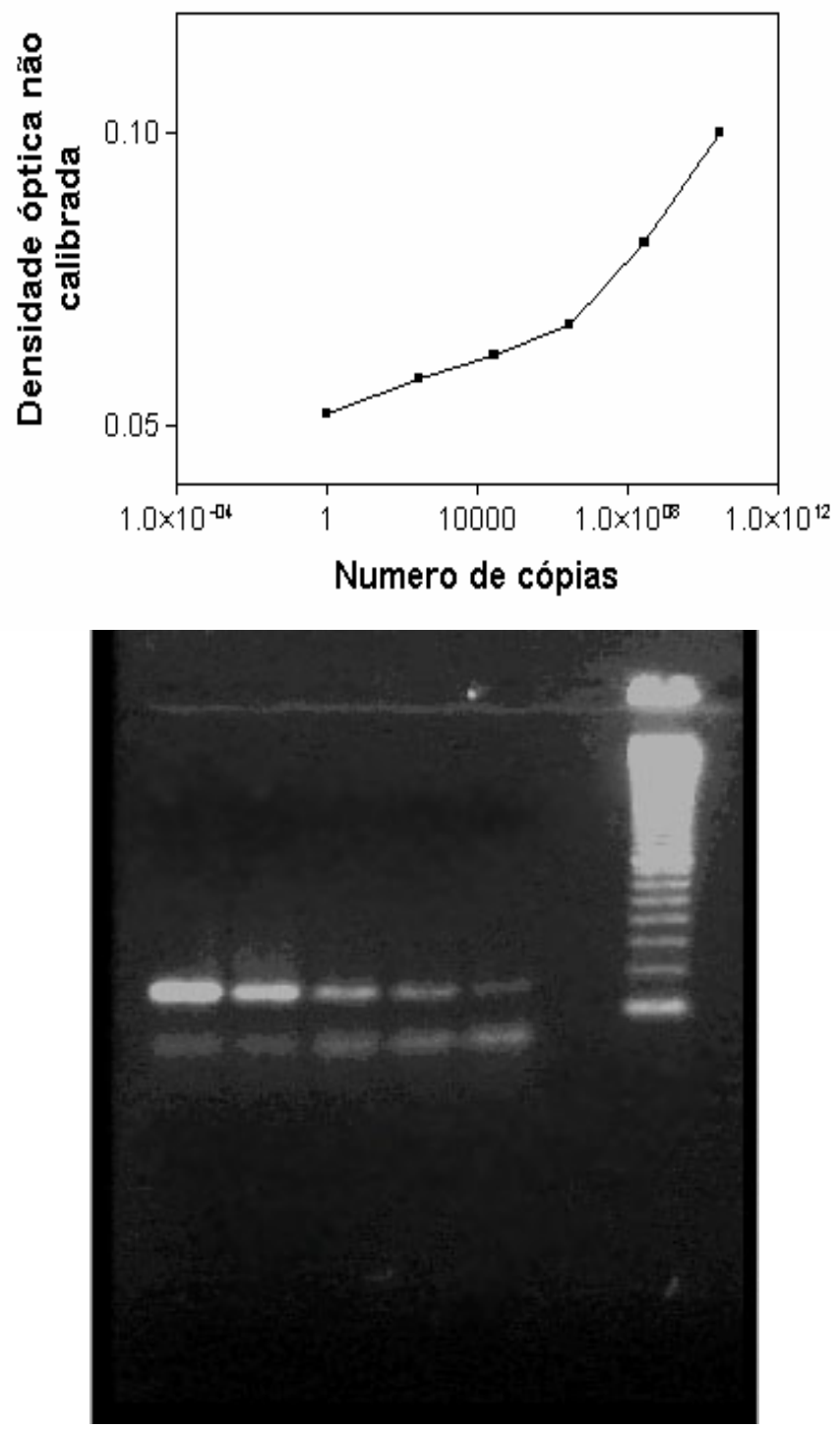

Figura 3: Foto de gel de agarose $2 \%$ demonstrando as diluições seriadas para titulação do inserto e a estimativa do limite de detecção da reação em cadeia por polimerase.

\subsection{7) CONTROLE NEGATIVO}

Como controle negativo, foi utilizada água MilliQ estéril, em cada reação processada.

Algumas precauções foram tomadas, no sentido de prevenir a 
contaminação da PCR e, conseqüentemente, resultados falso-positivos: todos os reagentes foram aliquotados em pequenas quantidades e armazenados em frascos estéreis. Os reagentes e também as amostras foram manuseados em capelas de fluxo laminar. Foram, também, utilizadas áreas distintas do laboratório para as etapas de extração do DNA, preparo dos reagentes, amplificação e detecção dos produtos obtidos.

\subsection{8) CONTROLE INTERNO}

A fim de se verificar a ocorrência de inibição da amplificação, cada amostra foi submetida à reação em duplicata, acrescentando-se ao segundo tubo igual volume de amostra padrão, servindo como controle interno da amplificação. (LAKEMAN FD, 1995). Foram consideradas positivas as amostras que apresentaram produtos de amplificação de 173 pb, em ambos os tubos de reação e, negativas as amostras em que foi identificado fragmento de igual tamanho apenas nos tubos em que havia adição do controle interno. Na ausência de banda, novo protocolo de extração foi empregado. A presença de DNA foi confirmada, através da amplificação do gene da $\beta$-globina (SAIKI et al, 1985), nas amostras que se mostraram negativas, sem inibidores, cujos pacientes possuíam quadro clínico fortemente sugestivo de LEMP. 


\subsection{9) AVALIAÇÃO DA TÉCNICA DE DETECÇÃO DO DNA DO VJC NO LÍQÜOR, PARA DIAGNÓSTICO DA LEMP}

Não nos foi possível neste estudo, avaliar a sensibilidade da PCR no diagnóstico da LEMP, uma vez que a técnica diagnóstica descrita como "gold standard", que consiste na demonstração do vírus ou seu material genético em tecido cerebral (através de biópsia ou necrópsia) havia sido realizada em apenas três pacientes.

Em dois desses casos a PCR mostrou-se positiva, enquanto que a biópsia cerebral demonstrou achados histopatológicos característicos de LEMP em apenas um deles. No terceiro caso, não foi possível estabelecer um diagnóstico, por qualquer das técnicas.

Com o intuito de avaliar a especificidade da presença do DNA no líquor dos pacientes para diagnóstico de LEMP, amostras de líquido céfalorraquidiano de pacientes com e sem aids, apresentando quadros neurológicos de diferentes etiologias, foram também testadas.

O DNA-VJC foi pesquisado em vinte e seis amostras de líquor de pacientes com aids e diagnóstico de neurocriptococose. Foram testadas, também, amostras de dezesseis pacientes com diagnóstico de neurotoxoplasmose e de dois pacientes com diagnóstico de polineuropatia por CMV. A PCR foi negativa em todas as amostras.

No grupo de pacientes sem aids foram testadas vinte amostras de líquor de pacientes com diagnóstico de neurocisticercose e em trinta e oito amostras de pacientes com diagnóstico de neurosífilis, além de oito amostras de pacientes com meningites bacterianas (Neisseria meningitides 
e Streptococcus pneumoniae).O DNA do vírus JC não foi encontrado em nenhuma das amostras.

Finalmente, onze amostras de líquor com parâmetros laboratoriais normais foram testadas, com resultado negativo em todas. Uma amostra de líquor com achados laboratoriais sugestivos de meningite linfomonocitária também foi testada, onde houve amplificação do DNA de poliomavirus.

Desta forma, a PCR para o vírus JC foi negativa em 119/120 casos não LEMP, demonstrando uma especificidade de 99,17\%. 


\section{4) RESULTADOS}

Foram avaliados, no período de agosto de 2000 a agosto de 2003, cinqüenta e seis amostras de líquor de pacientes com aids, que apresentavam quadro clínico-neurológico compatível com LEMP (encefalite focal e ausência de lesões expansivas de substância branca na tomografia computadorizada de crânio). Quarenta e oito desses pacientes eram provenientes do Instituto de Infectologia Emílio Ribas, sete provenientes do Hospital das Clínicas da Faculdade de Medicina da Universidade de São Paulo e um do Instituto da Criança do Hospital das Clínicas da Faculdade de Medicina da Universidade de São Paulo. Destes, trinta e três pacientes eram do sexo masculino $(58,9 \%)$. Todos os pacientes receberam esquema HAART e tratamento empírico para neurotoxoplasmose (NTX) até exclusão deste diagnóstico por ressonância magnética, sorologia específica ou confirmação de outro diagnóstico. $O$ número de células $T \mathrm{TD}_{4}+$ variou entre 1 e 739 céls $/ \mathrm{mm}^{3}$ (média 94,2 céls $/ \mathrm{mm}^{3}$, mediana 41,5 céls $/ \mathrm{mm}^{3}$ ). No líquor, a citologia mostrou-se normal em quarenta e seis pacientes $(82,1 \%)$, com proteinorraquia aumentada em trinta e três pacientes $(58,9 \%)$ e hipoglicorraquia em treze pacientes $(23,2 \%)$.

Todos os pacientes apresentavam tomografia computadorizada de crânio demonstrando lesões hipoatenuantes de substância branca. Destes, vinte e cinco $(44,6 \%)$ realizaram ressonância magnética.

A reação em cadeia por polimerase para pesquisa do DNA de poliomavirus $\mathrm{JC} / \mathrm{BK}$ foi realizada em todos os pacientes, mostrando-se positiva em vinte e sete destes $(48,2 \%)$. 
Nesses pacientes foi amplificado o fragmento de 173 pares de bases, correspondente a região $\mathrm{T}$ dos poliomavirus. As amostras positivas foram, então, submetidas a tipagem com enzima de restrição Bam $\mathrm{H} 1$, dando origem a dois fragmentos menores (120 e 53 pb), característicos do vírus $\mathrm{JC}$.

Exemplos de produtos obtidos a partir da amplificação das amostras e a posterior tipagem com enzima de restrição são mostrados nas figuras $4 \mathrm{e}$ 5. 


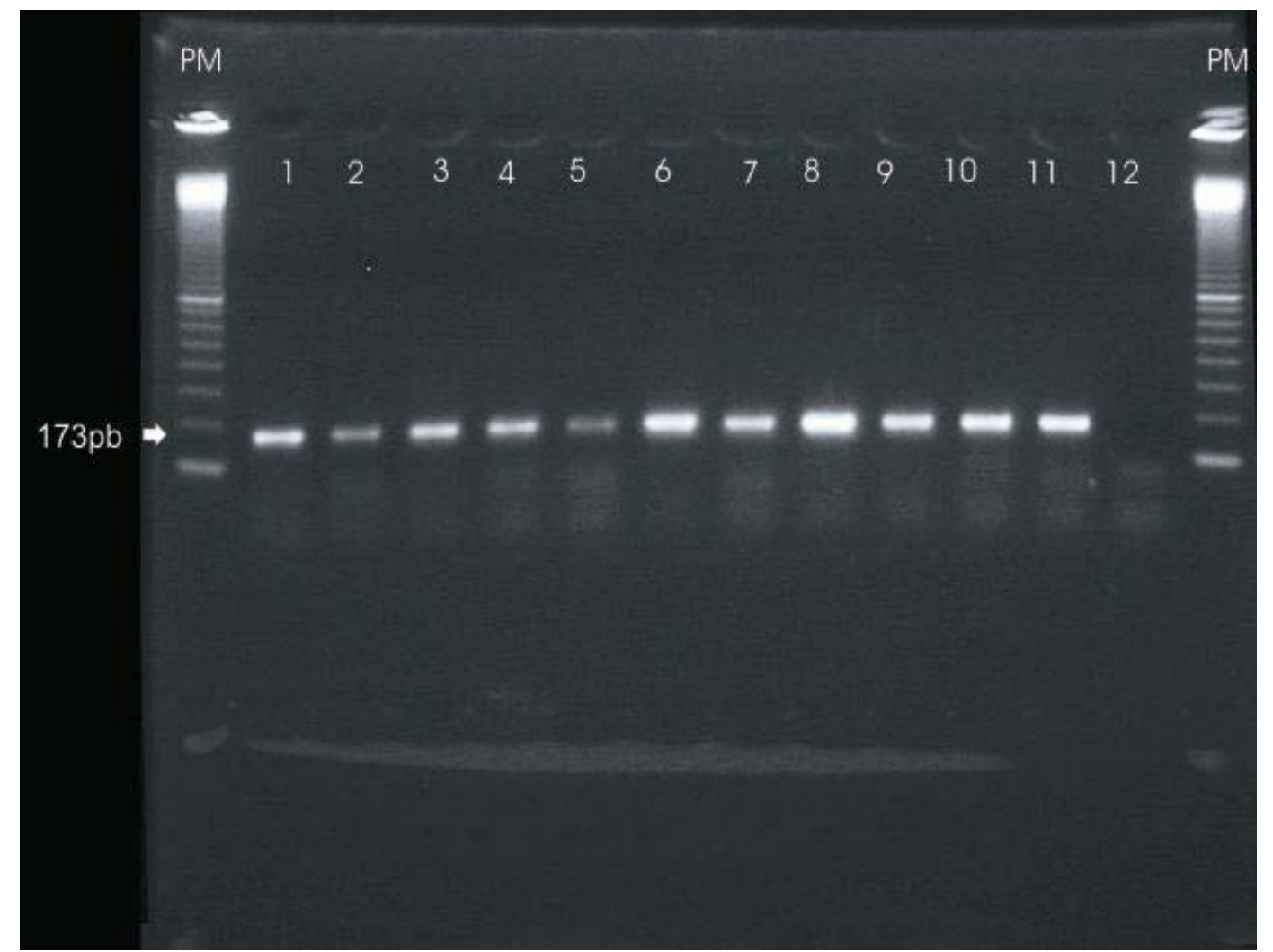

Figura 4: Foto de gel de agarose $2 \%$ marcado com brometo de etídio, contendo produtos de 173 pb obtidos com os primers PEP ${ }_{1}$ e PEP 2, linhas 1 a 11; linha 12, controle negativo. Nas extremidades, marcador de peso molecular de $100 \mathrm{pb}$. 


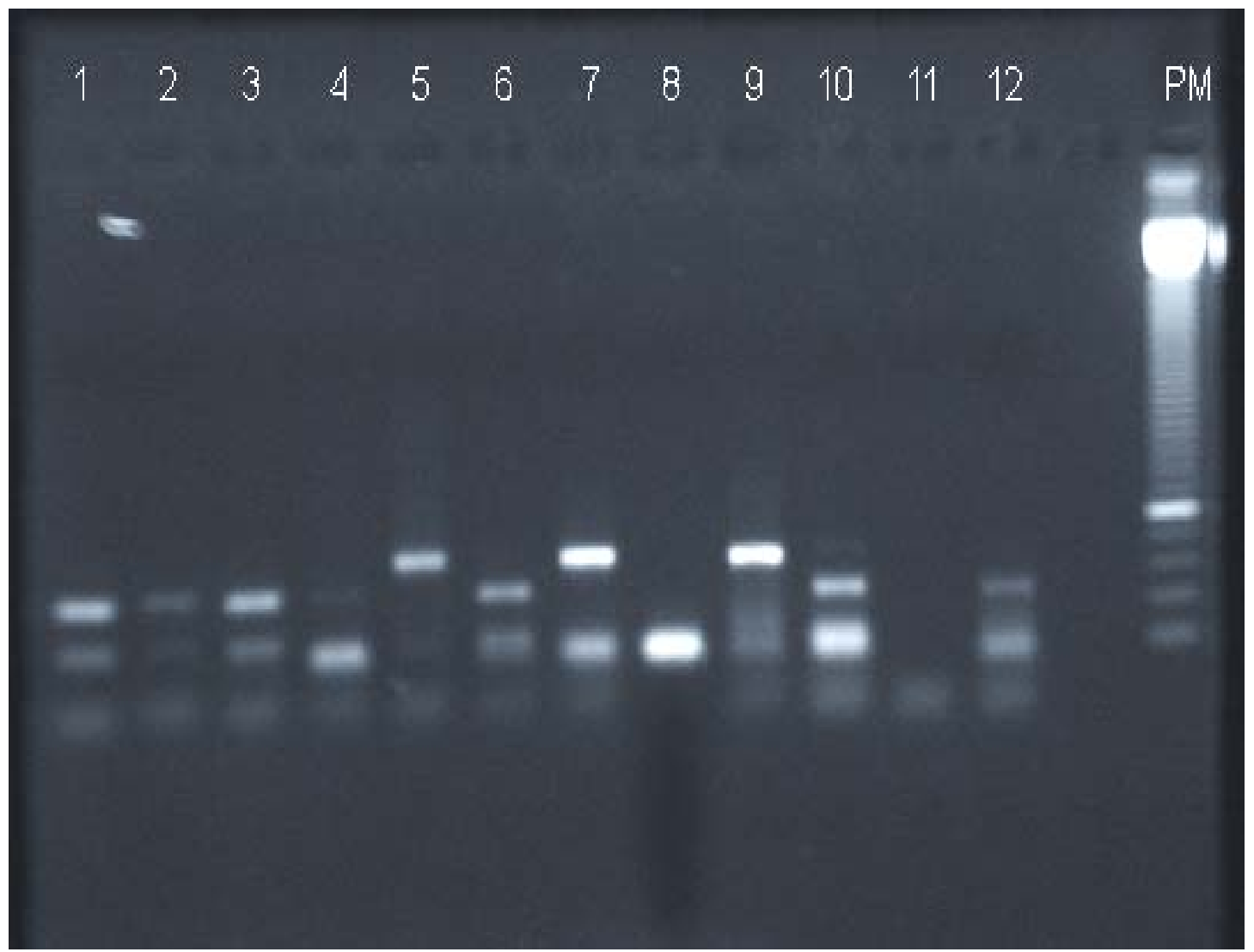

Figura 5: Foto de gel de agarose $A 1000$ (Gibco BRL) 2\% marcado com Brometo de Etídio. Linhas 1, 2, 3, 4, 6, 8, 10 e 12: padrão característico do vírus JC (obtenção de dois fragmentos de 120 e 53 pb), após digestão com enzima de restrição Bam H1. Linhas 5, 7, 9: amostras sem digestão. Linha 11: controle negativo. 
Com base nos resultados da PCR, os pacientes com diagnóstico clínico-tomográfico compatível com LEMP foram separados em dois grupos: o grupo DNA-VJC positivo e o grupo DNA-VJC negativo e analisados separadamente.

\section{1) PACIENTES COM DNA-VJC POSITIVO NO LÍQUOR}

Vinte e sete pacientes foram positivos para o vírus JC através da técnica de PCR, sendo, dezessete do sexo masculino (62,9\%). A idade destes pacientes variou entre 11 e 52 anos (média 35,4; mediana 36). A contagem de células $T C D_{4}+$ neste grupo variou de 1 a 210 céls $/ \mathrm{mm}^{3}$, sendo a média de 44,72 céls $/ \mathrm{mm}^{3}$ e a mediana de 21,0 céls $/ \mathrm{mm}^{3}$. Em vinte e um desses pacientes $(77,8 \%)$, a contagem de células $\mathrm{T} \mathrm{CD}_{4}+$ foi inferior a 100 céls $/ \mathrm{mm}^{3}$.

A ocorrência de infecções prévias ao quadro neurológico foi relatada em vinte e dois pacientes $(81,5 \%)$. A encefalopatia focal foi a doença definidora da aids em cinco pacientes $(18,5 \%)$.

Cinco dos pacientes com PCR positiva para VJC efetuaram nova coleta de líquor. Um deles após vinte dias da primeira coleta, um após três meses, e os outros após cinco, seis e oito meses. Em todos, observou-se negativação da PCR nesta segunda amostra.

Em um dos pacientes com PCR positiva para o vírus JC, havia positividade da PCR para o HSV em amostra de líquor colhida sete dias 
antes. Este paciente foi submetido a tratamento com aciclovir e, na amostra definidora da presença do DNA do vírus JC, colhida sete dias após, a presença do DNA do HSV foi negativa.

Dois pacientes foram submetidos à biópsia estereotáxica, sem determinação diagnóstica em um deles e achados histopatológicos característicos de LEMP no segundo paciente.

Um terceiro paciente foi submetido à trepanação, sem diagnóstico.

Nenhum dos vinte e sete pacientes com DNA-VJC positivo no líquor apresentou outro diagnóstico etiológico para o quadro encefalítico.

\section{2) PACIENTES COM DNA - VJC NEGATIVO NO LÍQUOR}

No segundo grupo de pacientes foram avaliados vinte e nove pacientes com lesões focais não expansivas de substância branca e DNA VJC negativo.

A idade neste grupo variou entre vinte e quatro e quarenta e nove anos (média 40,4 céls $/ \mathrm{mm}^{3}$; mediana 41,0 céls $/ \mathrm{mm}^{3}$ )

Destes, dezesseis eram do sexo masculino (55,2\%). A contagem de células $T C D_{4}+$ neste grupo variou entre 7 e 739 céls $/ \mathrm{mm}^{3}$, com média de 148,5 céls $/ \mathrm{mm}^{3}$ e mediana de 32,11 céls $/ \mathrm{mm}^{3}$.

Em quinze pacientes $(51,7 \%)$, o número de células $T \mathrm{CD}_{4}+$ foi inferior a 100 céls $/ \mathrm{mm}^{3}$.

A distribuição do número de células $T \mathrm{CD}_{4}+$ nos dois grupos de pacientes está sumarizada na figura 6. 


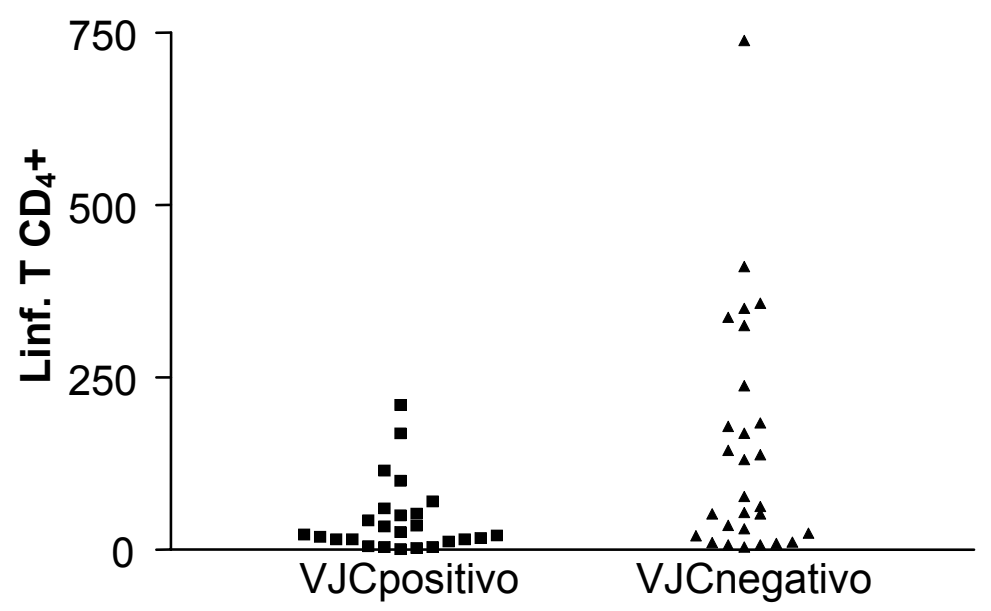

Figura 6: Contagem de células $T \mathrm{TD}_{4}+$ em relação à detecção do DNA do vírus JC através da reação em cadeia por polimerase

As médias e medianas do número de células $\mathrm{TCD}_{4}+$ nos dois grupos (DNA -VJC positivo e DNA -VJC negativo) foram analisadas através do programa Excel - Analyse it, com o Teste de Análise de Variância. A diferença entre os valores encontrados nas médias dos dois grupos foi estatisticamente significante $(p<0,01)$.

As medianas foram analisadas através do teste Mann-Whitney. As diferenças entre os dois grupos foram, também, estatisticamente significantes $(p<0,02)$.

Em vinte e três pacientes DNA-JCV negativos foi possível a realização de diagnóstico diferencial: nove $(39,13 \%)$ receberam diagnóstico 
de neurotoxoplasmose; cinco $(27,74 \%)$, complexo cognitivo motor pelo HIV; três $(13,04 \%)$, neurotuberculose; dois casos de esclerose múltipla-"like" (8,7\%), um caso de encefalite herpética (4,35\%), um abcesso por Aspergillus sp $(4,35 \%)$, um acidente vascular cerebral (AVC) $(4,35 \%)$ e um caso de linfoma não-Hodgkin (4,35\%).

Nos seis pacientes restantes em que a PCR para o vírus JC foi negativa, não houve um diagnóstico final. Neste grupo de pacientes, em especial, a tomografia computadorizada revelou áreas de hipoatenuação sugestivas de LEMP, porém, a contagem de células $\mathrm{TCD}_{4}+$ mostrou-se mais elevada do que a observada no grupo de pacientes DNA-VJC positivos (média 323,5 céls $/ \mathrm{mm}^{3 ;}$ mediana 331 céls $/ \mathrm{mm}^{3}$ ). 


\section{5) DISCUSSÃO}

O vírus HIV está associado a várias infecções oportunistas, bem como neoplasias do sistema nervoso central, sendo este o segundo órgão mais comumente afetado em pacientes com aids.

Dentre as infecções neurológicas podemos citar como mais freqüentes a toxoplasmose, a criptococose, a infecção pelo citomegalovirus, a leucoencefalopatia multifocal progressiva, além dos quadros demenciais causados pelo próprio HIV (COLLAZOS et al, 2003).

Embora diversos relatos indiquem que a incidência de algumas infecções neurológicas entre pacientes com aids tenha diminuído, como conseqüência da introdução da terapia HAART, elas permanecem como a maior causa de morbidade e mortalidade nesse grupo de pacientes (COLLAZOS et al, 2003).

A incidência da leucoencefalopatia multifocal progressiva, ao contrário de outras complicações neurológicas, na vigência da terapia HAART, demonstrou relativa estabilização (SACKTOR et al, 2001) ou, ainda, ligeiro aumento, embora não estatisticamente significante (AMMASSARI et al, 2000).

Tradicionalmente, o prognóstico da LEMP tem sido sombrio, com uma média de sobrevivência de um a seis meses pós-diagnóstico (FONG et al, 1995; GASNAULT, 1999). Entretanto, uma minoria significativa de pacientes $(\sim 8 \%)$ apresenta um curso mais benigno da doença, com remissão e, até mesmo, recuperação espontânea. Alguns fatores, tais como altas contagens 
de células $\mathrm{TCD}_{4}+$ ao diagnóstico, baixa carga viral de HIV, a LEMP como doença definidora de aids, baixos níveis do vírus JC no líquor e seu subseqüente "clearence", além da ausência de progressão neurológica nos dois meses seguintes ao diagnóstico, estão associados à sobrevivência prolongada nesses pacientes (SKIEST, 2002).

Alguns estudos têm documentado um aumento de sobrevida entre os pacientes com LEMP que são tratados com HAART (CINQUE et al, 1998; GASNAULT et al,1999). Assim, a terapia HAART transformou-se no padrão para tratamento de pacientes com LEMP, embora a doença possa, ocasionalmente, desenvolver-se em pacientes recebendo HAART ou, ainda, não haver melhora neurológica a despeito da melhor resposta virológica e imunológica frente à terapia.(De LUCA et al 1999, De LUCA et al 2000, RAZONABLE et al, 2001)

Embora não exista, ainda, tratamento específico comprovadamente eficaz para a LEMP, vários relatos vêm sendo feitos, sugerindo possíveis benefícios com o emprego de diversas drogas, tais como o Ara-c, zidovudina, alfainterferona. Estudos demonstraram, entretanto, que essas drogas são ineficazes ou sua eficácia é desconhecida (HOU \& MAJOR, 1998).

Estudo recente descreveu os resultados de um ensaio clínico fase II utilizando o Topotecan, um análogo semi-sintético de camptothecan. Onze pacientes foram arrolados no estudo, com resposta ao tratamento em três deles (ROYAL W IIl et al, 2003). 
O cidofovir é considerado a droga mais promissora para o tratamento da LEMP. Alguns estudos têm sugerido uma boa resposta ao tratamento com este antiviral, especialmente nos casos em que a terapia HAART não resulta em reconstituição imune suficiente (De LUCA A, 1999; ZIMMERMMAN et al, 2001).

Contudo, ainda não existem estudos controlados, duplo-cegos e aleatórios para comprovação de sua eficácia.

O desenvolvimento de novos antivirais com ação anti-VJC tem levado a um grande interesse por técnicas que permitam o diagnóstico específico, rápido e pouco invasivo da LEMP.

Neste sentido, a associação de novas técnicas de diagnóstico por imagem, bem como a introdução da reação em cadeia por polimerase em líquido cefalorraquidiano para detectar ácidos nucléicos dos microorganismos responsáveis tem contribuído para aumentar a possibilidade de fazer o diagnóstico "in vivo" (AMMASSARI et al, 2000).

Os estudos encontrados na literatura descrevem como reação "padrão ouro" para diagnóstico de LEMP, a demonstração do vírus ou seu material genético em tecido cerebral, através de biópsia estereotáxica ou necrópsia (Antinori et al, 2000). O uso da biópsia cerebral, entretanto, é controverso, devido à relação custo (complicações e riscos ocupacionais) e benefício (capacidade para determinar uma mudança na terapia) (ANTINORI et al, 2000). Estudo realizado em 1992 por CHAPPELL e col demonstrou acurácia diagnóstica da biópsia cerebral em apenas $80 \%$ dos pacientes. (CHAPPELL et al, 1992). 
Um estudo multicêntrico realizado em 2000 demonstrou diagnóstico definitivo, através da biópsia em $86 \%$ dos pacientes, com morbidade caracterizada por rebaixamento de consciência e sinais focais transitórios em $7,5 \%$ destes, e mortalidade relacionada à biópsia ocorrendo em 3,1\% dos pacientes (ANTINORI et al, 2000).

Embora não haja qualquer recomendação do CDC (Center for Disease Control) no sentido de substituir a biópsia cerebral, vários autores concordam que a biópsia cerebral deve ser reservada para aqueles pacientes com achados atípicos nos diagnósticos clínico- radiológico ou cuja PCR tenha resultado negativa para o VJC (SADLER \& NELSON, 1997).

Diversos estudos têm comparado as técnicas de PCR em líquor com a detecção do vírus em fragmento de tecido cerebral, encontrando especificidade variável entre 92\% e 100\% (GIBSON et al 1993, WEBER et al 1994, FONG et al 1995, CINQUE et al 1998) e sensibilidade entre $72 \%$ e $100 \%$, dependendo dos primers empregados (CINQUE et al 1998).

Demonstra-se, dessa maneira, uma tendência ao uso de técnicas moleculares para diagnóstico etiológico da LEMP, analogamente ao que ocorreu no diagnóstico da encefalite herpética.

Durante vários anos, a biópsia cerebral foi considerada o único método seguro para o estabelecimento diagnóstico da encefalite herpética, devido, especialmente, aos seus altos índices de sensibilidade e especificidade e à possibilidade de um diagnóstico diferencial no caso de doenças que mimetizam a HSE (encefalite herpética) (WHITLEY et al 1989; SOONG et al 1991; HANLEY et al 1987). Esta prática, entretanto, pode 
acarretar uma série de complicações, tais como a ocorrência de convulsões em mais de $50 \%$ dos pacientes, supostamente devido ao edema provocado pela biópsia (ANDERSON et al, 1991).

Em nosso estudo foram avaliadas amostras de líquor de cinqüenta e seis pacientes com encefalopatia focal e diagnóstico clínico-radiológico sugestivo de LEMP. A suspeita clínica foi confirmada em vinte e sete pacientes $(48,2 \%)$, onde seqüências específicas do VJC foram identificadas, demonstrando uma alta prevalência do DNA do vírus JC neste grupo de pacientes. Esses resultados indicam que a pesquisa do DNA do vírus JC em líquor, através da reação em cadeia por polimerase constitui-se em excelente alternativa diagnóstica em pacientes com aids e lesão focal não expansiva de substância branca, por ser rápido, pouco invasivo, bastante específico e de custo relativamente baixo.

A maior limitação do nosso estudo consistiu na ausência de determinação da sensibilidade do diagnóstico de LEMP através da reação em cadeia por polimerase, devido à ausência de diagnóstico histológico.

A especificidade do encontro do DNA do vírus JC em quadros neurológicos compatíveis com LEMP foi avaliada utilizando-se amostras de líquor de pacientes com outras etiologias.

O DNA de poliomavirus foi amplificado em amostras de líquor de um paciente com quadro clínico diferente da LEMP. Esse paciente, com diagnóstico de meningite linfomonocitária, apresentou amplificação do DNA do poliomavirus, demonstrando uma especificidade da PCR de 99,17\%. 
A hipótese de contaminação foi descartada, uma vez que, diversos controles negativos foram utilizados e o DNA do poliomavirus JC não foi demonstrado em nenhum deles. Com relação às características epidemiológicas dos nossos pacientes, confirmou-se a observação de outros pesquisadores, que estabelecem que a LEMP aparece em fases avançadas da infecção pelo HIV, com baixo número de linfócitos TCD4+ e elevada viremia do HIV (BERGER et al, 1987; MAJOR et al, 1992; FONG et al, 1995).

Em vinte e três dos vinte e nove pacientes com DNA-VJC negativos, pôde-se estabelecer outros diagnósticos etiológicos, sendo a neurotoxoplasmose o quadro mais freqüente, confirmado em nove destes $(30,4 \%)$.

Aqui, mais uma vez, fica confirmada a utilidade da pesquisa do DNA do vírus JC pela PCR, já que nos casos negativos, fica evidenciada a necessidade de uma investigação diagnóstica mais aprofundada, para detecção de outros agentes eventualmente envolvidos na etiologia do quadro neurológico.

Assim, na presente casuística, a maioria dos quadros de encefalite focal com lesão não expansiva de substância branca era passível de tratamento específico (neurotoxoplasmose, neurotuberculose, HSV, aspergilose).

Um grupo de pacientes, em especial, chamou-nos a atenção; seis indivíduos possuíam quadro clínico-radiológico compatível com LEMP, sem detecção, entretanto, do DNA do vírus JC ou qualquer outro agente etiológico. A única diferença apresentada entre os indivíduos desse grupo 
daqueles com PCR positiva para JC, resumia-se a uma maior contagem de células $\mathrm{T}^{\mathrm{C}} \mathrm{CD}_{4}+$. Revisando a literatura, encontramos alguns relatos semelhantes. Segundo MAJOR e col (1992), um retorno a imunocompetência levaria à eliminação do vírus do sistema nervoso central. Um estudo realizado por GASNAULT e col (2003), avaliou o papel da resposta imune celular (linfócitos $\mathrm{T} \mathrm{CD}_{4+}$ ) em pacientes com LEMP ativa e em pacientes sobreviventes a essa doença, observando o clearence do DNA do VJC no líquor (GASNAULT et al, 2003). É possível, portanto, que este grupo de pacientes realmente tenha apresentado um quadro de LEMP, porém, com a melhora da imunidade celular, evidenciada pela maior quantidade de células $\mathrm{TCD}_{4+}$ em relação aos VJC positivos, que o DNA do vírus JC já não estivesse presente no líquor. Uma outra possibilidade para esses resultados negativos poderia ser a carga viral do VJC presente no líquor encontrar-se abaixo dos limites de detecção do teste. Um estudo realizado por FONG e col encontrou, utilizando o mesmo protocolo descrito por ARTHUR e col, uma positividade em dezessete de vinte e três pacientes (73,9\%). Entretanto, três dessas amostras (17,6\%) eram fracamente positivas, sendo detectadas somente após a hibridação dos produtos de PCR (FONG et al, 1995).

Existem, entretanto, relatos de novos quadros neurológicos, associados, aparentemente ao emprego da terapia HAART. Gray e col (2003) descrevem novas variantes de leucoencefalopatias graves em HIV, com intenso infiltrado de linfócitos e macrófagos perivasculares, possivelmente devido a uma resposta exagerada do sistema imune 
recentemente reconstituído e formas crônicas de encefalites por HIV, VZV, toxoplasmose ou LEMP, associadas, possivelmente a sobrevivência prolongada, nas quais nem o processo inflamatório, tampouco o agente etiológico pôde ser detectado (GRAY et al, 2003). DU PASQUIER \& KORALNICK postularam que um quadro indistinguível da LEMP pode surgir no contexto de uma síndrome da reconstituição imune. Numa análise de trinta e nove pacientes com LEMP, cinco (13\%) apresentaram a forma inflamatória da doença. Destes, dois desenvolveram LEMP logo após o início da terapia HAART, concomitantemente a recuperação imune (diminuição da carga viral de HIV e aumento na contagem de células $T \mathrm{CD}_{4}$ +); três pacientes demonstravam sinais de inflamação no sistema nervoso central, caracterizados pela presença de infiltrados inflamatórios na biópsia cerebral (DU PASQUIER \& KORALNICK). Esses dados indicam que reações inflamatórias em LEMP não são infreqüentes, e estão, geralmente, associadas a um melhor prognóstico. 


\section{6) CONCLUSÕES}

1. No presente estudo, constatou-se uma alta prevalência do DNA do poliomavirus humano $\mathrm{JC}$ em amostras de líquor de pacientes com aids e quadro clínico característico de LEMP (encefalite focal e lesão não expansiva de substância branca). Em nosso grupo de pacientes a prevalência foi de $48,2 \%$.

2. Em pacientes com aids e encefalite focal com lesões não expansivas de substância branca do sistema nervoso central, com PCR negativa para o VJC, está indicada uma investigação diagnóstica mais aprofundada, já que, a maioria desses casos apresenta outra etiologia, na maior parte das vezes passível de tratamento específico. 
7) ANEXOS

ANEXO 1
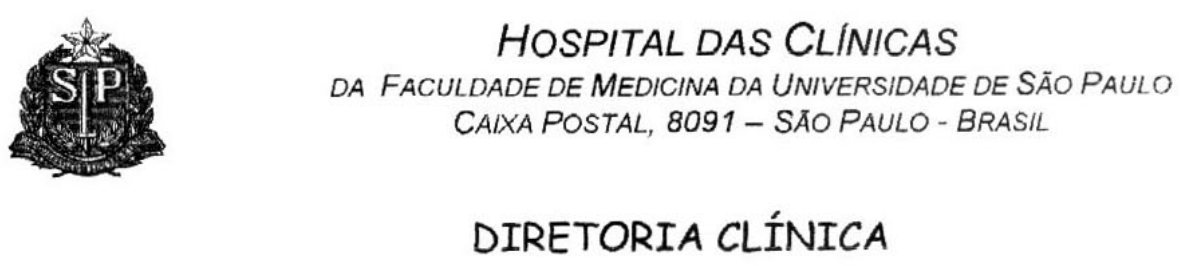

HOSPITAL DAS CLINICAS

DA FACULDADE DE MEDICINA DA UNIVERSIDADE DE SÃo PAULO

CAIXA POSTAL, 8091 - SÃO PAULO - BRASIL

DIRETORIA CLÍNICA

\section{Comissão de Ética para Análise de Projetos de Pesquisa}

\section{APROVACÃO}

A Comissão de Ética para Análise de Projetos de Pesquisa - CAPPesq da Diretoria Clínica do Hospital das Clínicas e da Faculdade de Medicina da Universidade de São Paulo, em sessão de 19.12.02, APROVOU o Protocolo de Pesquisa $n^{\circ}$ 800/02, intitulado: "Detecção do DNA do vírus JC em amostras de líquido cefalorraquidiano de pacientes com AIDS e lesões não expansivas de substância branca do sistema nervoso central", apresentado pelo Departamento de DOENÇAS INFECCIOSAS E PARASITÁRIAS, bem como o Termo de Consentimento Livre e Esclarecido.

Pesquisador(a) Responsável: PROF. DR. CLÁUDIO SÉRGIO PANNUTI Pesquisador(a) Executante: DRA. MARIA CRISTINA DOMINGUES FINK

CAPPesq, 19 de Dezembro de 2002.

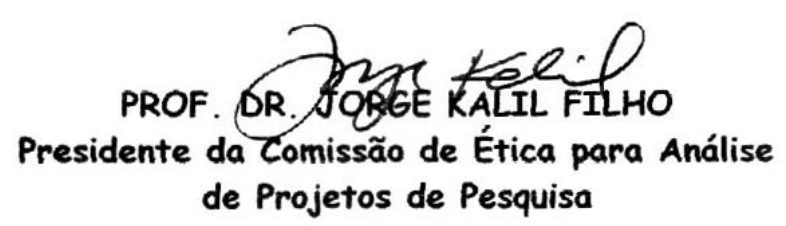

OBSERVAÇÃO: Cabe ao pesquisador elaborar e apresentar à CAPPesq, os relatórios parciais e final sobre a pesquisa (Resoluçäo do Conselho Nacional de Saúde $n^{\circ}$ 196, de 10.10.1996, inciso IX.2, letra " $c$ "). 
ANEXO 2

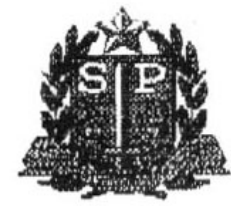

\section{SECRETARIA DE ESTADO DA SAÚDE COORDENAÇÃO DOS INSTITUTOS DE PESQUISA INSTITUTO DE INFECTOLOGIA "EMILIO RIBAS" COMITÉ DE ÉTICA EM PESQUISA}

Av. Dr. Arnaldo, 165 - Cerquelra Cesar - Săo Paulo - SP

CEP: $01246-900$ - TEL: $3896-1406$

\section{PARECER}

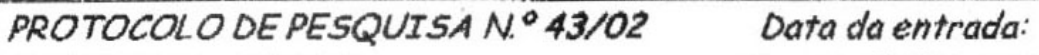

Título da Pesquisa: "Detecçäo do DNA do virus JC em amostras de Líquido Cefalorraquidiano de pacientes com Aids $e$ lesốes não expansivas de substância branca do sisteme nervoso central".

Pesquisador Responsável: Dr. Augusta César Penalva de Oliveira CONSIDERAÇÕES:

O Comitê de Ética em Pesquisa aprova o Protocolo de Pesquisa.

(X) APROVADO

( ) APROVADO COM RECOMENDAÇŐES

( ) REPROVADO

( ) COM PENDÊNCIAS- OBS.: a ausência de resposta em 60 dias, acarretará em arquivamento do processo por falta de interesse do pesquisador.

TEMÁTICA ESPECIAL

CONEP

$\square$ SIM SIM

$\square$ NÃO

RIA)

$\square$ NÃO

SVS (SECRETARIA DE VIGILÂNCIA SANITÁRIA)
SIM
$\square$ NÃO

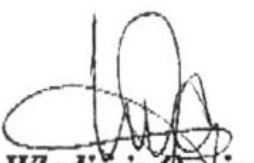

Dr. Wadimir Qukiroz

Coordenador do Comitê de Ética em Pesquisa-IIER 
8) REFERÊNCIAS BIBLIOGRÁFICAS

AL-SOUD, W.A. \& RADSTRÖM, P. Purification and characterization of PCRinhibitory components in blood cells. J. Clin. Microbiol., v. 39, p. 485493, 2001.

AGOSTINI, H.T.; RYSCHKEWITSCH, C.F.; STONER, G.L.. Genotype profile of human polyomavirus $\mathrm{JC}$ excreted in urine of immunocompetent individuals. J. Clin. Microbiol., v. 34, p.159- 164, 1996.

AGOSTINI, H.T.; YANAGIHARA, R.; DAVIS, V.; RYSCHKEWITSCH, C.F.; STONER, GL. Asian genotypes of JC virus in native americans and in a pacific island population: markers of viral evolution and human migration. Proc. Natl. Acad. Sci. USA., v. 94, p. 14542- 14546, 1997.

AGOSTINI H.T., RYSCHKEWITSCH C.F., BRUBAKER G.R., SHAO J., STONER G.L. Five complete genomes of JC virus type 3 from africans and african Americans. Arch. Virol., v.142 p. 637-655, 1997.

AGOSTINI H.T., RYSCHKEWITSCH C.F., STONER G.L. JC virus type 1 has multiple subtypes: three new complete genomes. J. Gen. Virol., v.79 p. 801- 805, 1998. 
AGOSTINI H.T., SHISHIDO-HARA Y., BAUMHEFNER R.W., SINGER E.J., RYSCHKEWITSCH C.F., STONER G.L. JC virus type 2: definition of subtypes based on DNA sequence analysis of ten complete genomes. J. Gen. Virol., v.79, p. 1143-1151, 1998.

AGOSTINI H.T., DUCKHUT A., JOBES D.V., GIRONES R., SCHLUNCK G., PROST M.G., FRIAS C., TRALLER E.P., RYSCHKEWITSCH C.F., STONER G.L. Genotypes of JC virus in East, Central and Southwest Europe. J. Gen. Virol., v. 82, p. 1221- 1331, 2001.

AKSAMIT A.J., SERVER J.L., MAJOR E.O. Progressive multifocal leukoencephalopathy: JC virus detection by in situ hybridization compared with immunohistochemistry. Neurology, v. 36, p. 499-504, 1986.

AMEMIYA K., TRAUB R., DURHAM L., MAJOR E.. Interaction of a nuclear factor-1-like protein with the regulatory region of the human polyomavirus JC virus. J. Biol. Chem., v. 264, p. 7025- 7032, 1989.

ANTINORI A., AMMASSARI A., DE LUCA A.. Diagnosis of AIDS-related focal brain lesions: A decision-making analysis based on clinical and neuradiologic characteristics combined with polymerase chain reaction assays in CSF. Neurology, v. 48, p. 687-694, 1997. 
ANTINORI A., AMASSARI A., GIANCOLA M.L., CINGOLANI A., GRISETTI S., MURRI R., ALBA L., CIANCIO B., SOLDANI F., LARUSSA D., IPPOLITO G., DE LUCA A. Epidemiology and prognosis of AIDSassociated progressive multifocal leukoencephalopathy in the HAART era. J. Neurovirol. v. 7, p. 323-8, 2001.

ANTINORI A., AMASSARI A., LUZZATI R., CASTAGNA A., MASERATI R. Role of brain biopsy in the managemente of focal brain lesions in HIVinfected patients. Neurology, v. 54, p. 993- 997, 2000.

ARTHUR R.R., SHAH K.V., BAUST S.J. Association of BK viruria with hemorrhagic cystitis in recipients of bone marrow transplants. N. Engl. J. Med., v. 315, p. 230- 234, 1989.

ARTHUR R.R. BK and JC virus infection in recipients of bone marrow transplants. J. Infect. Dis., v. 158, p. 563-569, 1988.

ARTHUR R.R, DAGOSTIN S., SHAH K.V. Detection of BK virus and JC virus in urine and brain tissue by the polymerase chain reaction. J. Clin. Microbiol., v. 27, p. 1174-1179, 1989.

ASTROM K.E., MANCALL E.L., RICHARDSON E.P. Jr. Progressive Multifocal Leukoencephalopathy. Brain, v. 81, p. 93-127, 1958. 
BAROUCH D H, HARRISON S. C. Interactions among the major and minor coat proteins of polyomavirus. J. Virol., v. 68, p. 3982- 3989, 1994.

BEDRI J., WEINSTEIN W., De GREgORIO, VERITY M. A. Progressive multifocal leukoencephalopathy in acquired immunodeficiency syndrome. N. Engl. J. Med., v. 309, p. 492- 493, 1983.

BERGER J.R., KASZOVITZ B., DONOVAN POST J., DICKINSON G. Progressive Multifocal Leukoencephalopathy associated with human immunodeficiency virus infection. Ann. Int. Med., v. 107, p. 78-87, 1987.

BERGER J.R.; CONCHA M. Progressive Multifocal Leukoencephalopathy: the evolution of a disease once considered rare. J. Neurovirol., v. 1, p. 5-18, 1995.

BERGER J.R., LEVY R.M., FLOMENHOFT D., DOBBS M.. Preditive factors for prolonged survival in aquired immunodeficiency syndrome associated progressive multifocal leukoencephalopathy. Ann. Neurol., v. 44, p. 341-349, 1998.

BERGER J.R. \& MAJOR E.O. Progressive Multifocal Leukoencephalopathy. Semin. Neurol., v. 19, p. 193-200, 1999. 
BERGER J.R., CHAUHAN A., GALEY D., NATH A. Epidemiological evidence and molecular basis of interactions between HIV and JC virus. J. Neurovirol., v. 7, p. 329-338, 2001;

BERGSAGEL D.J., FINEGOLD M.J., BUTEL J.S. DNA sequences similar to those of simian virus 40 in ependyomomas and choroid plexus tumors of childhood. N. Engl. J. Med., v. 326, p. 988-993, 1992.

BLUM L.W., CHAMBERS R.A., SCHWARTZMAN R.J., STRELATZ L.J. Progressive multifocal leukoencephalopathy in acquired immune deficiency syndrome. Arch. Neurol., v. 42, p. 137-139, 1985.

BOFILL-MAS S., PINA S., GIRONES R. Documenting the epidemiologic patterns of polyomaviruses in human populations by studying their presence in urban sewage. Appl. Environm. Microbiol., v. 66, p. 238$245,2000$.

BOFILL-MAS S., FORMIGA-CRUZ M., CLEMENTE-CESARES., CALAFEL F., GIRONES R. Potential transmission of human polyomavirus through the gastrointestinal tract after exposure to virions or viral DNA. J. Virol., v. 75 , p. $10290-10299,2001 a$. 
BOFILL-MAS S. \& GIRONES R. Excretion and transmission of JCV in human populations. J. Neurovirol., v. 7, p. 345- 349, 2001 b.

BOGDANOVIC G., PRIFTKI P., HAMMARIN A. L. et al. Detection of JC virus in cerebrospinal fluid (CSF) samples from patients with progressive multifocal leukoencephalopathy but not in CSF samples from patients with Herpes simplex encephalitis, enteroviral meningitis or multiple sclerosis. J. Clin. Microbiol., v. 36, p. 1137-1138, 1998.

BROOKS B.R. \& WALKER D.L.. Progressive multifocal leukoencephalopathy. Neurol. Clin., v. 2, p. 299- 313, 1984.

BROWN P., TSAI T., GAJDUSEK G.D. Seroepidemiology of human papovaviruses: discovery of virgin populations and some unusual patterns of antibody prevalence among remote people of the world. Am. J. Epidemiol., v. 102, p. 331- 340, 1975.

CAMPOS M., MORAIS S., MONTEIRO L., JUSTIÇA B. A successful treatment of progressive multifocal leukoencephalopathy (PML) in an HIV+ haemophiliac A patient. Haemophilia, v. 8, p. 534, 2002.

CARBONE M., PASS H.I., RIZZO P.. Simian virus 40-like DNA sequences in human pleural mesothelioma. Oncogene., v. 9, p. 1781- 1790, 1994. 
CARBONE M., RIZZO P., PROCOPIO A. SV 40 sequences in human bone tumors. Oncogene., v. 13, p. 527- 535, 1996.

CAVANAUGH J.B., GREENBAUM D., MARSHALL A. Cerebral demyelination associated with disorders of reticuloendothelial system. The Lancet, v. 2, p. 524-529, 1959.

CENTERS FOR DISEASE CONTROL AND PREVENTION 1993. Revised classification system for HIV infection and expanded surveillance of definition for AIDS among adolescents and adults. MMWR Morb. Mortal. Wkly. Rep., v. 41, p. 1- 4, 1992.

CHAISSON R.E. \& GRIFFIN D.E. Progressive multifocal leukoencephalopathy in aids. JAMA, v. 264, p. 79- 82, 1990.

CHANG C.F., TADA H., KHALILI K.. The role of a pentanucleotide repeat sequence, AGGGAAGGGA, in the regulation of JC virus DNA replication. Gene, v. 148, p. 309- 314, 1994.

CHANG H., WANG M., TSAI R.T., LIN H.S., HUAN J.S., WAN W.C., CHANG D. High incidence of JC viruria in JC seropositive older individuals. J. Neurovirol., v. 8, p. 447- 51, 2002. 
CHAPPEL E.T., GUTHRIE B.L., ORENSTEIN J. The role of stereotactic biopsy in the management of HIV-related focal brain lesions. Neurosurg., v. 30, p. 825-859, 1992.

CHESTERS P.M., HERITAGE J., McCANCE J. Persistence of DNA sequences of BK virus and $\mathrm{JC}$ virus in normal human tissues and in diseased tissues. J. Infect. Dis., v. 147, p. 676- 683, 1983.

CHILDS R., SANCHES C., ENGLER H., PREUSS J., ROSENFELD S., DUNBAR C. High incidence of adeno- and polyomavirus-induced hemorrhagic cystitis in bone marrow allotransplantation for hematological malignancy following $\mathrm{T}$ cell depletion and cyclosporine. Bone Marrow Transplant., v. 22, p. 889- 893, 1998.

CIAPPI S., AZZI A., DE SANTIS R., LEONCINI F., STERRANTINO G., MAZZOTA F., MECOCCI L. Archetypal and rearranged sequences of human polyomavirus $\mathrm{JC}$ transcription control region in peripheral blood leukocytes and in cerebrospinal fluid. J. Gen. Virol., v. 80, p. 10171023, 1999.

CINQUE P., GIUDICI B., BOSSOLASCO S. The application of the polymerase chain reaction of cerebrospinal fluid in the clinical management of aids- related CNS disorders. AIDS Patient Care and 
STDs., v. 12, p. 287- 294, 1998.

CINQUE P., CASARI S., BERTELLI D. Progressive multifocal leukoencephalopathy, HIV and highly active antiretroviral therapy.

N.

Engl. J. Med., v. 339, p. 848-9, 1998.

COBB J.J., WICKENDEN C., SNELL M.E., HULME B., MALCOM A.D.B., COLEMAN D.V. Use of hybridot assay to screen for BK and JC polyomavirus in non- immunosupressed patients. J. Clin. Pathol., v. 40, p. $777-781,1987$.

COLLAZOS J. Oppportunistic infections of the CNS in patients with aids: diagnosis and management. CNS Drugs, v. 17, p. 869- 887, 2003.

COLEMAN D.V., WOLFENDALE M.R., DANIEL R.A., DHANJAL N.K., GARDNER S.D., GIBSON P.E., FIELD A.M. A prospective study of human polyomavirus in pregnancy. J. Infect. Dis., v. 142, p. 1- 8, 1980.

CUBUCK-DIMOPULO O., GRECO A., KUMAR A., KARLUK D., MITTAL K., JAGIRDAR J. BK infections in aids. Am. J. Surg. Pathol., v. 24, p. 145$151,2000$. 
DANIEL D.C., WORTMAN M.J., SCHILLER R.J., LIU H., GAN L., MELLEN J. S., CHANG C.H. Coordinate effects of human immunodeficiency virus type 1 protein Tat and cellular protein Pur $\alpha$ on DNA replication initiated at the JC virus origin. J. Gen. Virol., v. 82, p. 1543- 1553, 2001.

DANIEL R., SHAH K., MADDEN D., STAGNO S. Serological investigation of the possibility of congenital transmission of papovavirus JC. Infec. Immun., v. 33, p. 319- 321, 1981.

De LUCA A., FANTONI M., TARTAGLIONE T., ANTINORI A. Response to cidofovir after failure of antiretroviral therapy alone in AIDS-associated progressive multifocal leukoencephalopathy. Neurology, v. 52, p. 891892, 1999.

De LUCA A., GIANCOLA M. L., AMMASSARI A., GRISETTI S., CINGOLANI A. Cidofovir added to HAART improves virological and clinical outcome in AIDS-associated progressive multifocal leukoencephalopathy. AIDS, v. 14, p. F117-F121, 2000.

De LUCA A., CINGOLANI A., LINZALONE A., AMMASSARI A., MURRI R., GIANCOLA M.L., MAIURO G., ANTINORI A. Improved detection of JC vírus DNA in cerebrospinal fluid for diagnosis of aids-related progressive multifocal leukoencephalopathy. J. Clin. Microbiol., v. 34, p.13431346, 1996. 
De VIEDMA D.G., ALONSO R., MIRALLES P. Dual qualitative-quantitative nested PCR for detection of JC virus in cerebrospinal fluid: high potential for evaluation and monitoring of progressive multifocal leukoencephalopathy in aids patients receiving highly active antiretroviral therapy. J. Clin. Microbiol., v. 37, p.724- 728, 1999.

DORRIES K. \& ter MEULEN. Progressive multifocal leucoencephalopathy: detection of papovavirus JC in kidney tissue. J. Med. Virol., v. 11, p. 307-317, 1983.

DORRIES K., ARENDT G., EGGERS C. Nucleic acid detection as a diagnostic tool in polyomavirus JC induced progressive multifocal leukoencephalopathy. J. Med. Virol., v. 54, p.196-203, 1998.

DOLEI A., PIETROPAOLO V., GOMES E., DI TARANTO C., ZICCHEDDU M., SPANU M.A., LAVORINO C., MANCA M., DENEGER A.M.. Polyomavirus persistence in lymphocytes: prevalence in lymphocytes from blood donors and healty personnel of a blood transfusion center. J. Gen. Virol., v. 81, p.1967- 1973, 2000.

DUBOIS V., DUTRONC H., LAFON M.E., POINSOT V., PELLEGRIN J.L., RAGNAUD J.M., FERRER A.M., FLEURY H.J.A. Latency and reactivation of $\mathrm{JC}$ virus in peripheral blood of human immunodeficiency 
virus type 1- infected patients. J. Clin. Microbiol., v. 35, p. 2288- 2292, 1997.

ELSNER C. \& DÖRRIES K. Evidence of human polyomavirus BK and JC infection in normal brain tissue. Virology, v.191, p. 72- 80, 1992.

FLAEGSTAD T., TRAAVIK T., KOLMANNSKOG S., STOKLAND T. BK virus infection in children with cancer: serological response studied by hemaglutination inhibition, neutralization and IgG and IgM class especific ELISA tests. J. Med. Virol., v. 24, p. 33- 44, 1988.

FIELDS Virology - Section Two: Specific Virus Families

FONG I.W., BRITTON C.B., LUINSTRA K.E. Diagnostic value of detecting JC virus DNS in cerebrospinal fluid of patients with progressive multifocal leukoencphalopathy. J. Clin. Microbiol., v. 33, p. 484-486, 1995.

FRISQUE R.J., RIFKIN D.B. and WALKER D.L. Transformation of primary hamster brain cells with JC virus and its DNA. J. Virol., v. 35, p. 265269, 1980.

FRISQUE R.J., BREAM G.L., CANNELLA M.T. Human polyomavirus JC virus genome. J. Virol., v. 51, p. 458-469, 1984. 
GARDNER S.D. \& FIELD A.M. New human papovavirus (B.K.) isolated from urine after renal transplantation. The Lancet, v. 19, p.1253- 1257, 1971.

GARDNER S. D. Prevalence in England of antibody to human polyomavirus (BK). Br. Med. J., v. 1, p. 77- 78, 1973.

GASNAULT J., TAOUFIK Y., GOUJARD C. Prolonged survival without neurological improvement in patients with aids-related progressive multifocal leukoencephalopathy on potent combined antiretroviral therapy. J. Neurovirol., v. 5, p. 421-429, 1999.

GASNAULT J., KAHRAMAN M., de GOER de HERVE M.G., DURALI D., DELFRAISS J.F., TAOUFIK Y. Critical role of JC virus- specific CD4 Tcell responses in preventing progressive multifocal leukoencephalopathy. AIDS, v. 4, p. 1443-1449, 2003.

GIBSON P.E., KNOWLES W.A., HAND J.F. Detection of JC virus DNA in the cerebrospinal fluid of patients with progressive multifocal leukoencephalopathy. J. Med. Virol., v. 39, p. 278- 281, 1993.

GILLESPIE S.M., CHANG Y., LEMP G. Progressive multifocal leukoencephalopathy in persosn infected with human immunodeficiency virus, San Francisco, 1981-1989. Ann. Neurol., v. 30, p. 597-604, 
1991.

GOUDSMIT J., van DILLEN P.W., van STRIEN A. The role of BK virus in acute respiratory tract disease and presence of BKV DNA in tonsils. $\mathbf{J}$. Med. Virol., v. 10, p. 91-99, 1982.

GORDON J., GALLIA G. L., DEL VALLE L., AMINI S., KHALILI K. Human polyomavirus JCV and expression of myelin genes. J. Neurovirol. Suppl 2, p. S92- S97, 2000.

GREENLE J.E. Progressive Multifocal Leukoencephalopathy. Progress made and lessons relearned. N. Engl. J. Med., v. 338, p. 1378-1380, 1998.

GRINNELL B.W., PADGETT B.L., WALKER D.L. Comparision of infectious JC virus DNAs cloned from human brain. J. Virol., v. 45, p. 299-308, 1983.

GUO J., KITAMURA T., EBIHARA H., SUGIMOTO C., KUNITAKE T., TAKEHISA J., NA Y. Geographical distribution of the human polyomavirus JC types $\mathrm{A}$ and $\mathrm{B}$ and isolation of a new type of Ghana. J. Gen. Virol., v. 77, p. 919- 927, 1996. 
GUO J., SUGIMOTO C., KITAMURA T., EBIHARA H., KATO A., GUO Z., LIU J. Four geographically distinct genotypes of JC virus are prevalente in China and Mongolia: implications for the racial composition of modern China. J. Gen. Virol., v. 79, p. 2499- 2505, 1998.

HAMMARIN A.L., BOGDANOVIC G., SVEDHEM V. Analysis of PCR as a tool for detection of JC virus DNA in cerebrospinal fluid for diagnosis of progressive multifocal leukoencephalopathy. J. Clin. Microbiol., v. 34, p. 2929- 2932, 1996.

HAND R. Functions of T antigens of SV 40 and polyomavirus. Bioch. Bioph. Acta, v. 651, p. 1- 24, 1981.

HATWELL J.N. \& SHARP P.M. Evolution of human polyomavirus JC. J. Gen. Virol., v. 81, p. 1191- 1200, 2000.

HEDQUIST B.G., BRATT G., HAMMARIN A.L., GRANDIEN M., NENNESMO I., SUNDELIN B., SEREGARD S. Identification of BK virus in a patient with acquired immune deficiency syndrome and bilateral atypical retinitis. Ophthalmol., v.106, p.129- 132, 1999.

HOGAN T.F., BORDEN E.C., McBAIN J.A., PADGETT B.L., WALKER D.L. Human polyomavirus infections with JC virus and BK virus in renal 
transplant patients. Ann. Int. Med., v. 92, p. 373- 378, 1980.

HOLMAN R.C., JANSSEN R.S., BUELHER J.W. Epidemiology of progressive multifocal leukoencephalopathyin the United States: analyses of national mortality and AIDS surveilance data. Neurol., v. 41, p. 17331736, 1991.

HOU J. \& MAJOR E.O. The efficacy of nucleoside analogs against JC virus multiplication in a persistently infected human fetal brain cell line. $\mathbf{J}$. Neurol., v. 4, p. 451-456, 1998.

HOUFF S.A., MAJOR E.O., KATZ D.A., KUFTA C.V., SEVER J.L. Involvement of JC virus infected mononuclear cells from the bone marrow and spleen in the pathogenesis of progressive multifocal leukoencephalopathy. $\quad$ N. Eng. J. Med., v. 318, p. 301- 305, 1988.

JANSSEN R.S. Epidemiology and neuroepidemiology of human immunodeficiency virus infection. In: BERGER J.R., LEVY R.M., eds. AIDS and nervous system, 2. ed. Philadelphia: Lippincott-Raven, 1997. p.13-37.

JENSEN P.N. \& MAJOR E.O. A classification scheme for human polyomavirus JCV variants based on the nucleotide sequence of the 
noncoding regulatory region. J. Neurovirol., v. 7, p. 280- 287, 2001.

JOBES D.V., CHIMA S.C., RYSCHKEWITSCH G.F., STONER G.L. Phylogenetic analysis of 22 complete genomes of the human polyomavirus JC virus. J. Gen. Virol., v. 79, p. 2491- 2498, 1998.

JOBES D.V., FRIEDAENDER J.S., MGONE C.S., AGOSTINI H.T., KOKI G., YANAGIHARA R. New JC virus (JCV) genotypes from Papua New Guinea and Micronesia (Type 8 and Type 2E) and evolutionary analysis of 32 complete JCV genomes. Arch. Virol., v. 146, p. 2097-2113, 2001.

KALILII K., RAPAPPORT J., KHOURY G. Nuclear factors in human brain cells bind specifically to the JCV regulatory region. EMBO J., v. 7, p. 1205-1210, 1988.

KATZ D.A., BERGER J.R., HAMILTON B., MAJOR E.O., POST J.D. Progressive Multifocal Leukoencephalopathy complicating Wiskott-Aldrich syndrome. Arch. Virol., v. 51, p. 422-426, 1994.

KAHAN A.V., COLEMAN D.V., KOSS L.G. Activation of human polyomavirus infection - detection by cytologic technics Am. J. Pathol., v. 74, p. 326332, 1980. 
KENNEY S., NATARAJAN V., STRIKE D., KHOURY G., SALTZMAN N. P. JC virus enhancer- promoter active in human brain cells. Science, v. 226, p.1337- 1339, 1984.

KITAMURA T., ASO Y., KUNIYOSHI N., HARA K., YOGO Y. High incidence of urinary $\mathrm{JC}$ virus excretion in nonimmunosuppressed older patients. J. Infect. Dis., v. 161, p. 1128-1133, 1990.

KITAMURA T., KUNITAKE T., GUO J., TOMINAGA T., KAWABE K., YOGO Y. Transmission of the human polyomavirus JC virus occurs both within the family and outside the family. J. Clin. Microbiol., v. 32, p. 23592363, 1994.

KORALNICK I.J., BORDEN D., MAI V.X., LORD C.I., LETVIN N.L. JC virus DNA load in patients with and without progressive multifocal leukoencephalopathy. Neurology, v. 52, p. 253-264, 1999.

KRUPP L.B., LIPTON R.B., SWERDLOW M.L., LEEDS N.E., LLENA J. Progressive multifocal leukoencephalopathy: clinical and radiographic features. Ann. Neurol., v. 17, p. 344- 349, 1985.

KUNITAKE T., KITAMURA T., GUO J., TAGUCHI F., KAWABE K., YOGO Y. Parent to child transmission is relatively common in the spread of the human polyomavirus JC virus. J. Clin. Microbiol., v. 33, p.1448- 
$1451,1995$.

LEDNICK J.A., GARCEA R.L., BERGSAGEL D.J. Natural Simian virus 40 strains are present in human chloroids plexus and ependymoma tumors. Virology, v. 212, p. 710-717, 1995.

LAKEMAN F.D. \& WHITLEY R.J. Diagnosis of herpes simplex encephalitis: application of polymerase chain reaction to cerebrospinal fluid from brainbiopsed patients and correlation with disease. J. Infect. Dis., v.171, p. 857-63, 1995.

LESPRIT P., CHALINE-LEHMAN D., AUTHIER F.J., PONNELLE T., GRAY F., LEVY Y. BK virus encephalitis in a patients with aids and lymphoma. AIDS, v.15, p. 1196- 1199, 2001.

LIPTON H. L. Is JC virus latent in brain? Ann. Neurol., v. 29, p. 433434, 1991.

LIU C.K., HOPE A.P., ATWOOD W.J. The human polyomavirus, JCV, does not share receptor specificity with SV 40 on human glial cells. J. Neurol., v. 4, p. 49- 58, 1998 a.

LIU C.K., WEI G., ATWOOD W.J. Infection of glial cells by the human polyomavirus $\mathrm{JC}$ is mediated by an $\mathrm{N}$-linked glycoprotein containing 
terminal a (2-6)-linked sialic acids. J. Virol., v. 72, p. 4643- 4649, 1998b.

MAJOR E.O., AMEMIYA K., TORNATORE C.S., HOUFF S.A., BERGER J.R. Pathogenesis and molecular biology of progressive multifocal leukoencephalopathy, the JC virus-induced demyelinating disease of the human brain. Clin. Microbiol. Reviews, v. 5, p. 49- 73, 1992.

MATSIOTA-BERNARD P., de TRUCHIS P., GRAY F., FLAMENT-SAILLOUR M., VOYATZAKIS E., NAUCIEL C.. JC virus detection in the cerebrospinal fluid of aids patientes with progressive multifocal leukoencephalopathy and monitoring of the antiviral treatment by a PCR method. J. Med. Microbiol., v. 46, p. 256- 259, 1997.

McGUIRE D., BARHITE S., HOLLANDER H. JC virus DNA in cerebrospinal fluid of human immunodeficiency virus infected patients: predictive value for progressive multifocal leukoencephalopathy . Ann. Neurol., v. 37, p. 395- 399, 1995.

MARKOWITZ R.B., THOMPSON H.C., MUELLER J.F., COHEN J.A., DYNAN W.S. Incidence of BK virus and JC virus viruria in human immunodeficiency virus - infected and - uninfected subjects. J. Infect. Dis., v. 167, p. 13-20, 1993. 
MARTINELLI M., MARTINI F., RINALDI E., CARAMANICO L., MAGRI E., GRANDI E., CARINCI F., PASTORE A., TOGNON M. Simian virus 40 sequences and expression of the viral large $T$ antigen oncoprotein in human pleomorphic adenomas of parotid glans. Am. J. Pathol., v. 161, p. 1127-1133, 2002.

MELNICK J.L., ALLISON A.C., BUTEL J.S. Papovaviridae. Intervirology, v. 3, p.106-120, 1974.

MILLER J., BARRET R., BRITTON C. Progressive Multifocal Leukoencephalopathy in a male homosexual with T-cell immune deficiency. N. Eng. J. Med., v. 307, p. 1436-1438, 1982.

MONACO M.C.G., JENSEN P.N., HOU J., DURHAM L.C., MAJOR E.O. Detection of JC virus DNA in human tonsil tissue: evidence for site of initial viral infection. J. Virol., v. 72, p. 9918- 9923, 1998.

MORET H., GUICHARD M., MATHERON S. Virological diagnosis of progressive multifocal leukoencephalopathy: detection of JC virus DNA in cerebrospinal fluid and brain tissue of aids patients. J. Clin. Microbiol., v. 31, p. 3310- 3313, 1993. 
MORI M., KURATA H., TAJIMA M., SHIMADA H. .JC virus detection by in situ hybridization in brain tissue from elderly patients. Ann. Neurol., v. 29, p. 428- 434, 1991.

NAGASHIMA K., YAMAGUCHI K., YASUI K., OGIWARA H. Progressive Multifocal Leukoencephalopathy - Neuropathology and Virus Isolation. Acta Pathol. Japan., v. 31, p. 953-961, 1981.

NOORDAA J.V.D. \& van DILLEN P.W. Rise in antibodies to human papovavirus BK and clinical disease. $\quad$ B. Med. J., v. 1, p. 1471, 1977.

PADGET B.L., ZURHEIN G., WALKER D.J. Cultivation of papova-like virus from human brain with progressive multifocal leukoencephalopathy. The Lancet, v. 1, p.1257-1260, 1971.

PADGET B.L., WALKER D.J. Prevalence of antibodies in human sera against JC virus, an isloate from a case of progressive multifocal leukoencephalopathy. J. Infect. Dis., v.127, p. 467- 470, 1973.

PALELLA F.J. Jr, DELANEY K.M., MOORMAN A.C. AND HIV Outpatient Study Investigator. Declining morbidity and mortality among patients with advanced human immunodeficiency virus infection. N. Engl. J. Med., v. 338, p. 853-860, 1998. 
PHO M.T., ASHOK A., ATWOOD W.J. JC virus enters in human glial cells by clathrin dependent receptor mediated endocytosis. J. Virol., v. 74, p. 2288- 2292, 2000.

POWER C., KONG P.A., CRAWFORD T.O., WESSELINGH S., GLASS J.D., McARTHUR J.C., TRAPP B.D. Cerebral withe matter changes in acquired immunodeficiency syndrome dementia: alterations of the blood-brain barrier. Ann. Neurol., v. 33, p. 339- 350, 1993.

QUINLIVAN E.B., NORRIS M., BOULDIN T.W., SUZUKI K., MEEKER R., SMITH M.S., HALL C., KENNEY S. Subclinical central nervous system with JC virus in patients with aids. J. Infect. Dis., v. 166, p. 80- 85, 1992.

RAJ G. \& KHALILI K. Transcriptional regulation: lessons from the human neurotropic polyomavirus JCV. Virology, v. 213, p. 283- 291, 1995.

RAUSING A. \& AXELSON U. Progressive Multifocal Leukoencephalopathy in Chronic Lymphatic Leukaemia - Caused by Polyoma Virus? Scand. J. Haematol., v. 7, p. 184-194, 1970.

RAZONABLE R.R., AKSAMIT A.J., WRIGHT A.J., WILSON J.W. Cidofovir treatment of progressive multifocal leukoencephalopathy in a patient 
receiving highly active antiretroviral therapy. Mayo Clinic. Proceed., v. 76, p.1171- 1175, 2001.

REMENICK J., RADONOVICH M.F., BRADY J.N. Human immunodeficiency virus Tat transactivation: induction of a tissue-specific enhancer in a nonpermissive cell line. J. Virol., v. 65, p. 5641- 5646, 1991.

RICCIARDIELLO L., LAGHI L., RAMAMIRTHAM P., CHANG C.L., CHANG D.K., RANDOLPH A.E., BOLAND R. JC virus DNA sequences are frequently present in the human upper and lower gastrointestinal tract. Gastroenterol, v. 119, p. 1228-1235, 2000.

RICHARDSON E.P. Jr. Progressive Multifocal Leukoencephalopathy. N. Engl. J. Med., v. 265, p. 815-823, 1961.

ROSEN S., HARMON W., KRENSKY A.M. Túbulo-interstitial nephrits associated with polyomavirus (BK type) infection.

N. Engl. J. Med., v. 308, p. 1192-1196, 1983.

ROYAL W. $3^{\text {rd }}$, DUPONT B., McGUIRE D., CHANG L., GOODKIN K. et al Topotecan in the treatment of acquired immunodeficiency syndromerelated progressive multifocal leukoencephalopathy. J. Neurovirol., v. 9, p. 411- 419, 2003. 
SADLER M. \& NELSON M.R. Progressive multifocal leukoencephalopathy in HIV. Intern. J. STD \& AIDS, v. 8, p. 351- 357, 1997.

SAFAK M., BARRUCO R., DARBINYAN A., OKADA Y., NAGASHIMA K., KHALILI K. Interaction of JC vírus agnoprotein with $\mathrm{T}$ antigen modulates transcription and replication of the viral genome in glial cels. J. Virol., v. 75, p. $1476-1486,2001$.

SAIKI R.K., SCHARF S., FALOONA F. Enzymatic amplification of $\beta$ - globin genomic sequences and restriction site analysis for diagnosis of sikle cell anemia. Science, v. 230, p. 1350-1354, 1985.

SANDLER E.S., AQUINO V.M., GOSS-SHOET E., HINRICHS S., KRISHER K. BK papovavirus pneumonia following hematopoietic stem cell transplantation. Bone Marrow Transplant., v. 20, p. 163- 165, 1997.

SCHWEIGHARDT B., ATWOOD W.J. Glial cells as target of viral infection in the human central nervous system. Prog. in brain res., v.132, p. 721735, 2001.

SKIEST D.J. Focal neurological diseases in patients with acquired immunodeficiency syndrome. J. Clin. Infect. Dis., v. 34, p. 1660-2, 2002 
SMALL J.A., SCANGOS G.A., CORK L., JAY G., KHOURY G. The early region of human papovavirus JC induces dysmyelination in transgenic mice. Cell, v. 46, p.13-18, 1986.

SNIDER W.D., SIMPSON D.M., NIELSEN S., GOLD J.W.M., METROKA C.E., POSNER J.B. Neurological complications of acquired immune deficiency syndrome: analysis of 50 patients. Ann. Neurol., v.14, p. 403418, 1983.

SOEDA E., MIURA K., NAKASO A,, KIMURA G. Nucleotide sequence around the replication origin of polyoma virus DNA. FEBS LETTERS, v. 79, p. 383- 389, 1977.

STONER G.L., RYSCHKEWITSCH G.F., WALKER D.L. JC papovavirus large tumor $(T)$ antigen expression in brain tissues of acquired immunodeficiency syndrome (AIDS) and non-aids patients with progressive multifocal leukoencephalopathy. $\quad$ Proc. Nat. Acad. Sci. USA., v. 23, p. 2271- 2275, 1986.

STRICKLER H.D., ROSENBERG P.S., DEVESA S.S., HERTEL J., FRAUMENI F.J., GOEDERT J.J. Contamination of poliovirus vaccines with Simian Virus 40 (1955- 1963) e subsequent cancer rates. JAMA, v. 279 , p. 292- 295, 1998. 
SUGIMOTO C., HASEGAWA M., KATO A., ZHENG H.Y., EBIHARA H., TAGUCHI F., KITAMURA T., YOGO Y. Evolution of human polyomavirus JC: implications for the population history of humans. J. Molec. Evol., v. 54, p. 285- 297, 2002.

SUZUKI S., SAWA H., KOMAGOME R., ORBA Y., YAMADA M., OKADA Y., ISHIDA Y., NISHIHARA H., TANAKA S., NAGASHIMA K. Broad distribution of the JC virus receptor contrasts with a markers cellular restriction of virus replication. Virology, v. 286, p.100- 112, 2001.

SWEET T.M., DEL VALLE L., KHALILI K. Molecular biology and immunoregulation of human neurotropic JC virus in CNS. J. Cel. Physiol., v. 191, p. 249- 256, 2002.

TADA H., RAPPAPORT J., LASHGARI M.S., AMINI S., WONG-STAAL, KHALILI K. Trans-activation of the later promoter by the tat protein of type 1 human immunodeficiency virus in glial cells. Proc. Nat. Acad. Sci. USA, v. 87, p. 3479-3483, 1990.

TADA H., LASHGARI M.S., AMINI S. \& KHALILI K. Regulation of JCV promoter function: evidence that a pentanucleotide "silencer"repeat sequence AGGGAAGGGA down regulates transcription of the JC virus late promoter. Virology, v. 180, p. 327-338, 1991. 
TAGUCHI F., NAGAKI D., SAITO M., HARUYAMA C., IWASAKI K., SUZUKI T. Transplacental transmission of BK virus in human. J. Microbiol., v. 19, p. 395- 398, 1975.

TAGUCHI F., KAJIOKA J., MIYAMURA T. Prevalence rate and age of acquisition of antibodies against JC virus and BK virus in human sera. Microbiol. Immunol., v. 26, p.1057-1064, 1982.

TAOUFIK Y., DELFRAISSE J.F., GASNAULT J. Highly active antiretroviral therapy does not improve survival of patients with high JC virus load in the cerebrospinal fluid at progressive multifocal leukoencephalopathy diagnosis. AIDS, v. 14, p. 758- 759, 2000.

TELENTI A., MARSHALL W.F., AKSAMIT A.J. Detection of JC virus by polymerase chain reaction in cerebrospinal fluid from two patients with progressive multifocal leukoencephalopathy. Eur. J. Clin. Microbiol. Infect. Dis., v. 11, p. 253-254, 1992.

TORNATORE C., BERGER J.R., HOUFF S.A., CURFMAN B., MEYERS K., WINFIELD D., MAJOR E.O. Detection of JC virus DNA in peripheral lymphocytes from patients with and without progressive multifocal leukoencephalopathy. Ann. Neurol., v. 31, p. 455- 462, 1992. 
TUBRIDY M., WELLS C., LEWIS D., DCHON F. Unsuccessful treatment with cidofovir and cytarabine in progressive multifocal leukoencephalopathy associated with dermatomyositis. J. Royal Soc. Med., v. 93, p. 374$375,2000$.

TRUCHIS P., SAILLOUR F.M., URTIZBEREA J.A., HASSINE D., CLAIR B. Inefficacy of cytarabine in progressive multifocal leukoencephalopathy in AIDS. The Lancet, v. 342, p. 622- 623, 1993.

VAGO L., CINQUE P., SALA E., NEBULONI M., CALDARELLI R., RACCA S., FERRANTE P., TRABATTONI G., COSTANZI G. JCV-DNA and BKVDNA in the CNS tissue and CSF of aids patients and normal subjects. Study of 41 cases and review of the literature. J. Acq. Imm. Defic. Syndrome, v. 12, p. 139- 146, 1996.

WALKER D.L., PADGETT B.L., ZU RHEIN G.M. Human papovavirus (JC): induction of brain tumor in hamsters. Science, v. 181, p. 674- 676, 1973.

WEBER T., TURNER R.W., FRYE S. Specific diagnosis of progressive multifocal leukoencephalopathy by polymerase chain reaction.

J. Infect. Dis., v. 169, p. 1138-1141,1994. 
WEI G., LIU C.K., ATWOOD W.J. JC virus binds to primary human glial cells, tonsillar stromal cells and B- lymphocytes, but not to T lymphocytes. J. Neurovirol., v. 6, p. 127- 136, 2000.

WHITE III F.A., ISHAQ M., STONER G.L., FRISQUE R.J. JC virus DNA is present in many human brain samples from patients without progressive multifocal leukoencephalopathy. J. Virol., v. 66, p. 5726- 5734, 1992.

WHITEMAN M.L.H., POST M.J.D., BERGER J.R., TATE L.G., BELL M.D., LIMONTE L.P. Progressive multifocal leukoencephalopathy in $47 \mathrm{HIV}$ seropositive patients: neuroimaging with clinical and pathologic correlation. Radiology, v. 187, p. 233- 240, 1993.

YOGO Y., KITAMURA C., SUGIMOTO T., UEKI Y., ASO K., TAGUCHI F. Isolation of a possible archetypal JC virus DNA sequence from nonimmunocompromised individuals. J. Virol., v. 29, p. 2130-2138, 1990.

ZOLTICK P.W., MAYREDDY R.P.R., CHANG C.F., NORTHRUP B., KHALILI K., SCHWARTZMAN. Isolation and characterization of a type II JC virus from a brain biopsy of a patient with PML. J. Neurovirol., v. 1, p. 307315, 1995. 
ZURHEIN G.M. Polyoma-like virions in a human demyelinating disease. Acta Neuropathol., v. 8, p. 57-68, 1967. 